\title{
ALTERATION OF SEAGRASS SPECIES COMPOSITION AND FUNCTION OVER TWO DECADES
}

\author{
Fiorenza Micheli, ${ }^{1,5}$ Melanie J. Bishop, ${ }^{2,3}$ Charles H. Peterson, ${ }^{2}$ and José Rivera ${ }^{4}$ \\ ${ }^{1}$ Hopkins Marine Station, Stanford University, Pacific Grove, California 93950 USA \\ ${ }^{2}$ University of North Carolina at Chapel Hill, Institute of Marine Sciences, Morehead City, North Carolina 28557 USA \\ ${ }^{3}$ Department of Environmental Sciences, University of Technology Sydney, Broadway, NSW 2007 Australia \\ ${ }^{4}$ Department of Marine Sciences, University of Puerto Rico, Mayaguez, Puerto Rico 00681-9013 USA
}

\begin{abstract}
Changes in the species composition and structural characteristics of marine vegetated habitats in response to climate change or local anthropogenic impacts may alter their quality as habitat for associated fish and invertebrates. Summer densities and biomass of the eelgrass, Zostera marina, declined significantly between 1985 and 2004 in Bogue Sound, North Carolina, USA, within the present-day zone of biogeographic overlap in the distribution of this subtidal temperate species and the intertidal subtropical seagrass, Halodule wrightii. Zostera decline was associated with increased spring water temperatures and water nutrient concentrations. In contrast, Halodule did not exhibit a consistent trend of temporal change. Experimental seagrass transplants indicated that Halodule has the capacity to grow at depths greater than it currently occupies, suggesting that Halodule might, over time, replace Zostera. The abundance and diversity of infaunal invertebrates were lower in seagrass beds dominated by Halodule than in those dominated by Zostera or mixtures of the two species, suggesting that changing seagrass species composition affects associated faunal assemblages. Experimental deployment of artificial seagrass patches mimicking the structure of the two species showed that both depth and structural characteristics of seagrass explain differences in faunal assemblages. Epifaunal community structure differed significantly between structurally identical seagrass mimics deployed in intertidal and subtidal habitat, and invertebrates and fishes were significantly more abundant in artificial Zostera than Halodule patches at one of the two study sites. Synthesis of these results suggests that, in the event of continued Zostera loss, with or without replacement by Halodule, important habitat functions will be lost, and secondary productivity of these lagoonal ecosystems may significantly decrease.
\end{abstract}

Key words: climate change; competition; ecosystem functioning; eelgrass; estuary; eutrophication; habitat quality; Halodule wrightii; lagoon; long-term trends; macroinvertebrates; Zostera marina.

\section{INTRODUCTION}

Coastal marine environments are presently experiencing unprecedented rates of human-mediated change. In coastal seas, estuaries, and bays, over-extraction of marine resources, inputs of nutrients, pollutants, and sediments from land-based activities, direct destruction and degradation of habitat, and the introduction of exotic species have profoundly altered the structure and function of many ecosystems (Lotze et al. 2006). In addition, climate warming is projected to increase surface atmospheric temperatures by $1.1-6.4^{\circ} \mathrm{C}$ over the next 100 years (Intergovernmental Panel on Climate Change 2007). Such environmental change may negatively impact the performance and survival of marine organisms because many species already live close to their environmental tolerances (Somero 2002, Hughes et al. 2003).

Intertidal and shallow subtidal benthic organisms typically display strong vertical patterns in their

Manuscript received 22 September 2006; revised 8 June 2007; accepted 24 July 2007; final version received 12 October 2007. Corresponding Editor: D. C. Speirs.

${ }^{5}$ E-mail: micheli@stanford.edu distribution, and may be particularly susceptible to environmental change. In intertidal habitats, gradients of increasing biotic stress with increasing elevation have long served as a basis for predicting patterns of species distribution and interactions (e.g., Connell 1972). Similarly, in shallow subtidal habitats, strong environmental gradients caused by the attenuation of light with depth contribute to explaining patterns in the distribution of vascular aquatic plants (e.g., Bjork et al. 1999). Where biological zonation reflects local gradients in physical stress, zonation patterns are likely to shift as the environment changes (Lubchenco et al. 1993). Zonation shifts may also affect horizontal patterns of distribution, in addition to vertical ones, if the vertical range of a species collapses to zero, thereby setting a limit to the latitudinal distribution of a species (Harley et al. 2006). The extent to which these "squeeze" effects result in local and geographic range shifts is unknown.

Seagrasses are among the species that display strong patterns of vertical zonation and may be particularly susceptible to the "squeeze" effect. Species of Halodule often form extensive meadows in the intertidal belt of the tropical seas. Between the levels of mean low-water 
neap (MLWN) and mean low-water spring (MLWS), Halodule is replaced by Zostera, Thalassia, or Cymodocea. Abiotic factors, especially light, frequently determine the lower margin of seagrass beds (Dennison et al. 1993, Dalla Via et al. 1998). Biotic factors such as grazing (Tribble 1981) or competitive interactions (Williams 1987) also contribute to zonation of seagrass species.

Seagrass meadows are presently experiencing worldwide decline (Short and Wyllie-Echeverria 1996, Hemminga and Duarte 2000, Duarte 2002). Local human impacts, such as fishing disturbance, coastal eutrophication, siltation and burial, and the introduction of invasive species that outcompete native species, are often evident as causes for decline (Duarte 2002). In addition, significant correlations between decadal fluctuations of seagrass biomass and extent and climate variation increasingly point towards climate change effects (e.g., Marbà and Duarte 1997, Johnson et al. 2003).

Two species dominate seagrass communities of the Atlantic coast of North America. The eelgrass, Zostera marina L., is found from Nova Scotia to North Carolina. The shoalgrass, Halodule wrightii Ascher, ranges from North Carolina to the Gulf of Mexico and the Caribbean. In North Carolina, the two species overlap, with shoalgrass dominating in the late summer and early fall and eelgrass dominating in winter to early summer (Kenworthy 1981). Where the two species cooccur, shoalgrass extends into the upper intertidal, whereas eelgrass tends to be the more abundant at greater depths (Thayer et al. 1984).

The southernmost eelgrass beds on the U.S. east coast are those in the Bogue Sound-Back Sound region of North Carolina (see Plate 1). Therefore, a plausible consequence of climate warming would be loss or substantial depletion of eelgrass from this region. A shift to greater depth would minimize eelgrass exposure to increased water temperature. However, the lower limit of eelgrass distribution is set by light availability (Thayer et al. 1984), and thus such migration to deeper habitat might not be possible. Eelgrass' deep distribution may also enhance its susceptibility to increased water turbidity and decreased light levels typically associated with anthropogenic eutrophication, leading to greater decline of eelgrass compared to the intertidal shoalgrass. Furthermore, if present exclusion of shoalgrass from deeper depths is due, in part, to competition with eelgrass and not environmental constraints, eelgrass might be expected to be ultimately replaced by shoalgrass, the most tolerant of all seagrasses to variation in temperature (Phillips 1960) and increased nutrient loadings (Burkholder et al. 1992, 1994).

Seagrasses produce detritus that fuels food chains (Harrison and Mann 1975, Fenchel 1977, Thayer et al. 1977), provide nursery habitat for juvenile fish and shellfish (Peterson 1979, Heck and Thoman 1984, Orth et al. 1984, Beck et al. 2001), and baffle water flows and enhance deposition of larvae and suspended particles
(Peterson et al. 2004). Regardless of the specific causal mechanism of change in species composition, the substitution of sparser, wider-bladed, deeper-rooted eelgrass with denser, thinner-bladed, shallow rooted shoalgrass may alter the ecosystem functions provided by this habitat (see Orth et al. 1984, Peterson et al. 2004). Changes in the abundance, distribution, and species composition of seagrass beds may have cascading effects on whole assemblages of animals that utilize this important habitat.

Most studies on human-mediated change have focused on individual species, giving little consideration to ecological interactions (Kareiva et al. 1993, Harley et al. 2006). Focusing on ecological interactions and how the effects of changing habitat structure may cascade through whole assemblages is critical to predicting the impacts of local and global change to ecosystems. Here, we document multi-decadal changes in the distribution of two mid-Atlantic seagrass species, located at a natural ecotone, and through experiments demonstrate the potential consequences of shifts in seagrass species composition and structural characteristics on habitat provision by seagrasses to associated invertebrates and fish. Specifically we determine (1) changes in the species composition of seagrass beds in Bogue Sound, North Carolina, the southernmost extent of eelgrass along the east coast of the United States, over the past 19 years; (2) whether significant increase in water temperature and/or nutrient concentrations have occurred at this location; (3) whether shoalgrass can occupy the ecological niche presently occupied by eelgrass and consequently replace eelgrass in the event of its continued decline; (4) whether faunal assemblages vary with species composition of seagrass beds, comparing monospecific stands and mixed eelgrass and shoalgrass beds; and (5) whether possible differences in faunal assemblages between eelgrass and shoalgrass beds are primarily due to structural differences between the two seagrass species.

\section{Methods}

\section{Seagrass species composition}

Species composition of seagrass beds was monitored over a 19-year period to determine whether relative abundance of eelgrass and shoalgrass near the southernmost limit of eelgrass's geographic range has changed significantly in recent years. Sampling was conducted in Bogue Sound, North Carolina, USA (Fig. 1). Five shallow-subtidal mixed-species seagrass beds (Dog Island, 34 $41^{\prime} 30^{\prime \prime} \mathrm{N}, 76^{\circ} 54^{\prime} 28^{\prime \prime} \mathrm{W}$; Marker 42, $34^{\circ} 40^{\prime} 35^{\prime \prime} \mathrm{N}, 7^{\circ} 03^{\prime} 00^{\prime \prime} \mathrm{W}$; Huggins Island, 34 $39^{\circ} 55^{\prime \prime}$ N, $77^{\circ} 06^{\prime} 41^{\prime \prime} \mathrm{W}$; Piney Island, $34^{\circ} 40^{\prime} 59^{\prime \prime} \mathrm{N}, 77^{\circ} 00^{\prime} 32^{\prime \prime}$ W; Emerald Isle Bridge, $34^{\circ} 40^{\prime} 20^{\prime \prime}$ N, $77^{\circ} 03^{\prime} 44^{\prime \prime}$ W; Fig. 1) were sampled in early December 1985 and June 1986 by taking three $15 \mathrm{~cm}$ diameter, $15 \mathrm{~cm}$ deep cores from each grass bed. This sampling regime was not based on optimization studies of the sampling effort required to adequately quantify seagrass densities and species 


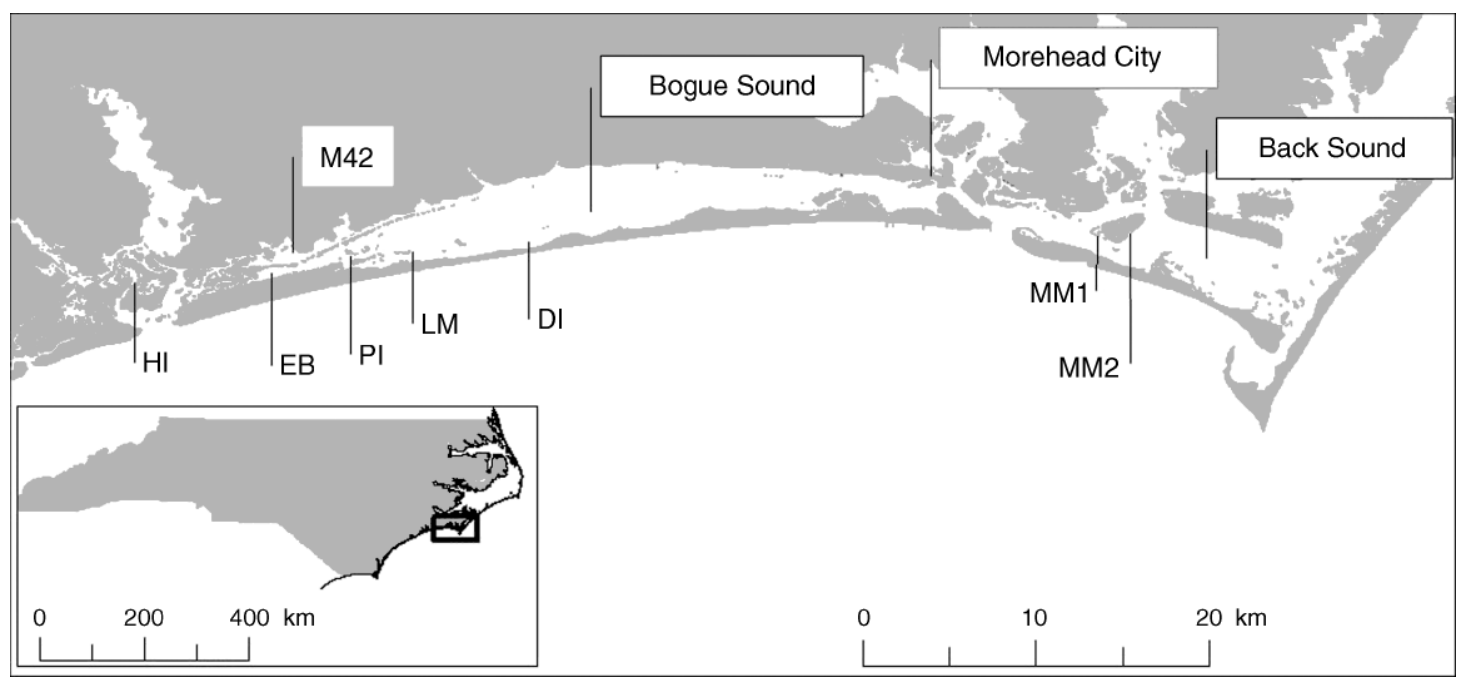

FIG. 1. Location of study sites within Bogue and Back Sounds, North Carolina, USA, where we conducted monitoring of seagrass species composition (Huggins Island [HI], Piney Island [PI], Emerald Isle Bridge [EB], Marker 42 [M42], Long Marsh [LM], and Dog Island [DI]) and faunal sampling and field experiments (sites 1 and 2 within Middle Marsh [MM1 and MM2]).

composition in these seagrass beds. Because our goal was to evaluate change over time, we minimized possible spatial confounding of our temporal comparisons by consistently sampling the same locations within the seagrass beds on each sampling date. To ensure that in different years sampling was conducted always within the same depth strata and locations within the seagrass beds, each site was marked with a PVC pole anchored deep in the sediment with a metal stake. Cores were collected at haphazard locations within an approximately $2 \mathrm{~m}$ radius from the pole, at the same depth as the pole. The same sites and one additional seagrass bed (Long Marsh, 34 $40^{\prime} 40^{\prime \prime}$ N, 76 $69^{\prime} 55^{\prime \prime}$ W; Fig. 1) were also sampled in early June 1986.

Sites were resampled identically in early June and December in 1994 and 1995, early June 1996, and early June and December 2004. From each core, we measured shoot density and biomass of each seagrass species. Biomass was measured after oven-drying the aboveground portion of plants at $65^{\circ} \mathrm{C}$ for three days. No measurements were conducted for belowground biomass. Plants were clipped at the sediment interface and only the aboveground portion was weighed. Separate analyses were performed on June and December data because this sampling design is unbalanced and the relative abundance of the two species differed greatly between summer and winter. Seagrass biomass ( $\mathrm{g}$ dry mass/core) and density data (no. seagrass shoots/core) were analyzed by two-way analysis of variance (ANOVA), with site and year of sampling as fixed factors. Prior to each analysis, the assumptions of normality and homogeneity of variances were examined and data were transformed when necessary using $\log (x+1)$. ANOVAs were followed by a posteriori Student-Newman-Keuls (SNK) tests to identify those treatment means that differed significantly at $\alpha=0.05$.

\section{Sea water temperature and nutrient concentrations}

Hourly measurements of surface water temperature during 1985-2005 were obtained from the nearby NOAA station at Duke Marine Laboratory (DUML), Beaufort. DUML is located in Pivers Island, Back Sound. Because of its proximity to the study sites in Bogue Sound, we assumed that these temperature data are representative of temperature variations at the study sites. Temporal trends in water temperatures were investigated using linear regression analysis.

The human population of Carteret County, North Carolina, bordering Bogue Sound, increased from 41092 to 62034 between 1980 and 2004 (U.S. Census Bureau). Coincident with this increase in population density, nutrient input from land-based activities may also have increased, though the actual extent of such increase is unknown. Unfortunately, continuous time series data of nutrient loadings or nutrient concentrations within Bogue or nearby Back Sound are not available, and therefore temporal trends cannot be examined directly. To assess the possibility of temporal increase in nutrient concentrations, we obtained snapshot measurements of nutrient concentrations conducted within the study area in the late 1960s and early 1990s (Thayer 1974, Shores 1994). We compared nutrient concentrations between these two sampling periods using a $t$ test, after expressing the data in common units $(\mu \mathrm{g} / \mathrm{L})$. We also conducted additional measurements at four locations within Bogue Sound in 1995, to determine how nutrient concentrations at a mid-point during our study compared to nutrient levels that have been experimentally shown to negatively affect eelgrass in our study area (Burkholder et al. 1992, 1994). On two occasions, in July and August 1995, six 1-L water samples were collected, during falling tides, at each of 
the four locations around our study sites in Bogue Sound (Fig. 1). Samples were frozen for nutrient analyses. We analyzed 2-3 subsamples from each water sample for nitrate and phosphate concentrations using a Lachat Quickchem IV autoanalyzer (Loveland, Colorado, USA).

\section{Seagrass transplant experiments}

To determine whether differing vertical distributions of eelgrass and shoalgrass are dictated by differing environmental requirements of the two species or mediated by interspecific competition, we conducted transplant experiments at Middle Marsh, Back Sound ( $35^{\circ} 41^{\prime}$ N, 76 $36^{\prime}$ W; Fig. 1), within the Rachel Carson National Estuarine Research Reserve. Sites were sheltered lagoons surrounded by marsh islands (Spartina alterniflora L.) with monospecific and mixed-species (Zostera marina and Halodule wrightii) seagrass beds. Salinity of these waters is high year round (32-34 PSU) due to relatively low riverine input and high tidal flushing through Beaufort and Barden's Inlets (H. J. Porter, unpublished data). We transplanted $808 \times 8 \times 8$ $\mathrm{cm}$ sediment plugs of each species to both intertidal (mean low water [MLW] -0.01 to $-0.05 \mathrm{~m}$ ) and shallowsubtidal (MLW -0.07 to $-0.14 \mathrm{~m}$ ) depths. At each depth, 40 plugs of each species were transplanted into a monospecific seagrass bed (eelgrass in the deeper areas and shoalgrass in the shallower areas), and 40 into adjacent unvegetated sediment. Thus, seagrass plugs were transplanted into three novel habitat types (unvegetated intertidal and shallow-subtidal sediments, and seagrass dominated by the other seagrass species, i.e., eelgrass plugs into shoalgrass beds, and shoalgrass plugs into eelgrass beds), as well as back into the same seagrass bed to test for possible effects of disturbance associated with transplantation. Experiments were replicated identically at two sites (MM1 and MM2; Fig. 1).

We transplanted the two species at different times of the year, November 1992 for the eelgrass and May 1993 for the shoalgrass because of the differing growing seasons of eelgrass (winter-spring) and shoalgrass (summer-fall) in North Carolina. We counted seagrass shoots in 10 randomly selected, transplanted seagrass plugs at the time of transplant, and in all transplanted plugs 1, 3, and 6 months after the beginning of the experiment. On each sampling date, we also quantified background seagrass densities and shoot lengths by counting shoots within $108 \times 8 \mathrm{~cm}$ quadrats randomly placed within the site, scattered around transplanted seagrass plugs.

To compare survivorship of transplanted seagrass among habitats, we performed analyses of variance on shoot densities of each seagrass species. ANOVAs had three orthogonal factors: time (fixed, four levels: 0, 1, 3, 6 months after transplant), treatment (fixed, four levels: intertidal seagrass beds, intertidal sandflats, subtidal seagrass beds, subtidal sandflats), and site (random, two levels: site 1 and 2). In toto, 160 seagrass plugs were transplanted in each season at each of the two sites (for a grand total of 640 seagrass plugs transplanted over the course of the entire study). However, so as to maintain temporal independence of shoot density estimates from different dates, each plug was only used to estimate shoot density on one of the four sampling dates, resulting in an $n$ of 10 replicates.

\section{Relative value of eelgrass and shoalgrass in habitat provision}

To determine whether utilization of seagrass beds by benthic fauna is dependent upon species composition of submerged aquatic vegetation, we sampled natural seagrass beds of varying composition at the two locations within Middle Marsh (MM1 and MM2; Fig. 1). At each location, samples were collected in October 1992 and May 1993 from three depths, deep (mean low water $[\mathrm{MLW}]-0.07$ to $-0.14 \mathrm{~m}$; dominated by eelgrass), intermediate (MLW -0.06 to $-0.11 \mathrm{~m}$; with similar abundances of eelgrass and shoalgrass), and intertidal (MLW -0.01 to $-0.05 \mathrm{~m}$; dominated by shoalgrass). On each sampling date, we collected 20 replicate sediment cores $(9.8 \mathrm{~cm}$ diameter, $15 \mathrm{~cm}$ deep) at haphazard locations from every depth at each location. Haphazard sample location was ensured by moving the corer among samples without looking at where it landed. At each depth, 10 of the cores were collected from at least $1 \mathrm{~m}$ inside the edge of the grass patch and the remaining 10 from unvegetated sediment close nearby.

Samples were placed on ice and transported back to the laboratory where they were sieved through a 1-mm sieve and preserved in $10 \%$ formalin solution stained with rose Bengal. After approximately one week, samples were transferred to $70 \%$ ethanol. Polychaetes, bivalves, gastropods, and crustaceans were counted and identified to family level. In addition we recorded shoot density and average blade length of each of the two seagrass species, eelgrass and shoalgrass, within each core.

The structure of invertebrate assemblages was compared among seagrass bed types (deep seagrass beds dominated by eelgrass, intermediate beds containing mixtures of eelgrass and shoalgrass, and intertidal beds dominated by the shoalgrass) and between sites (sites 1 and 2) using multivariate ordination and randomization tests. A matrix of similarities between each pair of samples was calculated using the Bray-Curtis similarity coefficient (Bray and Curtis 1957), after the raw data were transformed using the square-root transformation to decrease the influence of the most abundant species (Clarke and Warwick 1994). Nonmetric multidimensional scaling (nMDS) was used to produce twodimensional ordinations of the rank orders of similarities among samples (Clarke 1993). Initial ordinations included data from unvegetated habitats sampled at each of the three depths. However, major differences in the structure of assemblages from unvegetated and 
TABLE 1. Seagrass species composition and structural characteristics in the natural (1-3 m diameter) and artificial (1.1 $\mathrm{m}$ diameter) seagrass patches sampled for epifauna in May 1993, two months after artificial seagrass patches were deployed in the field.

\begin{tabular}{|c|c|c|c|c|c|c|}
\hline \multirow[b]{2}{*}{ Patch type } & \multicolumn{2}{|c|}{ No. shoots $/ \mathrm{m}^{2}$} & \multicolumn{2}{|c|}{ Shoot length $(\mathrm{cm})$} & \multicolumn{2}{|c|}{ Blade width $(\mathrm{cm})$} \\
\hline & Halodule & Zostera & Halodule & Zostera & Halodule & Zostera \\
\hline Halodule & $1558.4(330.0)$ & $916.6(171.7)$ & $9.1(0.6)$ & $14.9(0.8)$ & $0.1(0.0)$ & $0.3(0.01)$ \\
\hline Halodule mimic & 3000.0 & 0.0 & 15.0 & & 0.2 & \\
\hline Zostera & $0.0(0.0)$ & $1416.3(33.2)$ & & $21.7(1.0)$ & & $0.4(0.02)$ \\
\hline Zostera mimic & 0.0 & 1000.0 & & 15.0 & & 0.5 \\
\hline
\end{tabular}

Notes: Characteristics of natural seagrass patches were determined from two replicate cores $(9.8 \mathrm{~cm}$ in diameter) taken from each of four seagrass patches of each type at each of two sites in Middle Marsh, North Carolina, USA. For natural seagrass patches, mean densities (reported here with SE in parentheses) of each seagrass species were calculated across the 16 cores taken within each patch type at the two sites. The lengths of the longest blades in up to five seagrass shoots of each species, within each core, were measured. Artificial seagrass patches contained identical numbers and lengths of shoots; thus there is no variation associated with artificial seagrass densities and lengths.

vegetated habitats dominated the ordination results, preventing comparisons among seagrass beds. Thus, we repeated all multivariate analyses after excluding samples from unvegetated habitats.

Two-way analysis of similarity randomization tests (ANOSIM) were used to compare differences among seagrass bed types and sites (Clarke and Warwick 1994). Separate ANOSIMs were conducted on data collected in October and in May. The contributions of different species and species groups to observed patterns of dissimilarity among samples were quantified using SIMPER (Clarke and Warwick 1994). First, SIMPER was used to determine which taxa accounted for $50 \%$ of observed dissimilarity among samples collected in different seagrass bed types. Second, the best discriminating taxa were identified by selecting taxa with ratios of mean Bray-Curtis dissimilarity over the standard deviation of dissimilarity greater than or equal to 1 . High values of these ratios indicate that differences in the abundance of a particular taxon between seagrass beds were relatively consistent among samples (Clarke and Warwick 1994). Nonmetric multidimensional scaling, ANOSIM, and SIMPER have been used extensively to examine variation in multi-species assemblages, and test hypotheses about associations between such variation with experimental treatments, environmental gradients, and natural and/or anthropogenic disturbance. Several examples of applications are available online. ${ }^{6}$ All multivariate analyses were conducted using the software package PRIMER v. 5 (PRIMER-E Ltd, Plymouth, UK) (Clarke and Warwick 1994).

Analysis of variance was used to examine variation in total invertebrate abundances, invertebrate taxon richness (i.e., the total number of families identified in each sample), and separate abundances of infaunal and epifaunal invertebrates among seagrass beds dominated by shoalgrass, eelgrass, or mixtures of these two species. We used mixed ANOVA models with site as a random factor (two levels: site 1 and 2), and depth (three levels: deep, intermediate, and intertidal), habitat (two levels: vegetated and unvegetated habitat), and time (two

\footnotetext{
${ }^{6}\langle$ www.primer-e.com $\rangle$
}

levels: October and May sampling) as fixed factors. Because sample size varied slightly among different treatment combinations, the first 8 samples collected were used for each treatment combination in ANOVAs, i.e., the additional one to two samples collected for some habitat type $\times$ site $\times$ date combinations were excluded from the analyses. To examine whether this approach to selecting samples may have biased our results, we repeated the analyses with randomly selected samples. Results were qualitatively similar and are not reported here.

Differences in the faunal utilization of seagrass beds among the three depths may be due to (1) structural differences among seagrass beds of varying species composition, (2) water depth, or (3) an interaction between these two factors. To test the degree to which the structure of seagrass can influence utilization of the seagrass bed by fishes and crustaceans, we deployed artificial seagrass patches mimicking eelgrass and shoalgrass at different depths at the two Middle Marsh locations (Fig. 1). At each location, four artificial patches of eelgrass and four of shoalgrass were deployed on sand flats at each of two depths, shallow subtidal (MLW $-0.10 \mathrm{~m}$ ) and intertidal (MLW -0.01 m). Seagrass mimics were constructed by attaching green plastic ribbon (Synthetic Fibers, Newton, Pennsylvania, USA), cut to lengths and widths representative of natural populations of eelgrass or shoalgrass (Table 1), to a circular $1-\mathrm{m}^{2}$ base of $1.5-\mathrm{cm}$ polypropylene plastic mesh (InterNet, Minneapolis, Minnesota, USA). The densities at which the ribbon was arranged were three times greater for shoalgrass (3000 shoots $\left./ \mathrm{m}^{2}\right)$ than eelgrass (1000 shoots $\left./ \mathrm{m}^{2}\right)$ mimics, reflecting natural differences in density (Table 1). Each shoot comprised two blades of identical length and width. The plastic mesh was sewn to a metal frame and anchored to the bottom with metal staples.

Artificial seagrass patches were deployed in the field on 22 March 1993. Two months later, we sampled epifauna from artificial seagrass patches, natural seagrass patches (1-3 $\mathrm{m}$ in diameter), and unvegetated habitat at both shallow subtidal and intertidal locations. The short duration of the experiment allowed only for 

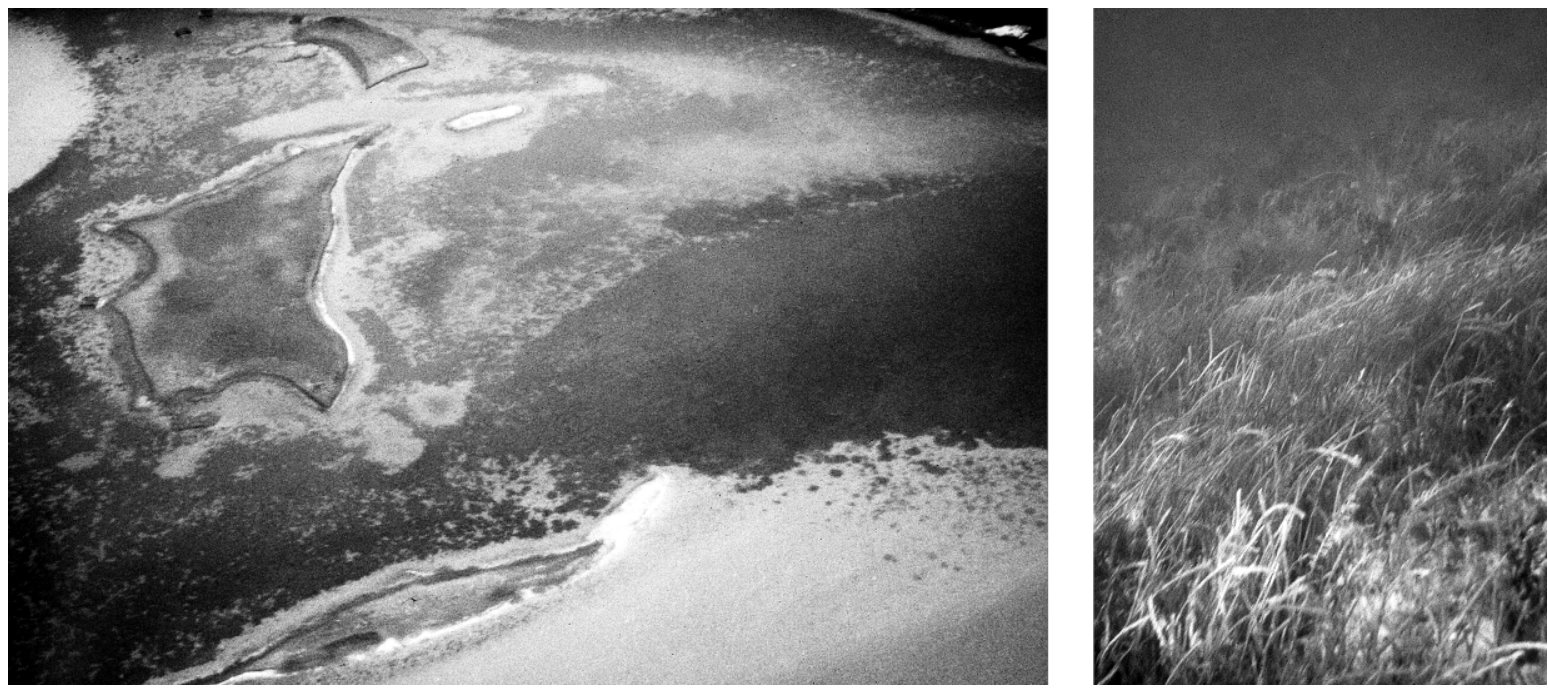

Plate 1. (Left) Aerial photograph of seagrass beds at Middle Marsh, Back Sound, North Carolina (USA), where surveys and experiments were conducted. (Right) Underwater photograph of a mixed Zostera marina and Halodule wrightii seagrass bed in Back Sound. Photo credits: (left) C. H. Peterson; (right) F. Micheli.

comparisons of short-term colonization of artificial seagrass patches, most likely through migration from adjacent seagrass beds and possibly partly through recruitment. Epifauna were sampled on incoming tides and slack high tides, when water depth was $0.5-0.8 \mathrm{~m}$, using $1-\mathrm{m}^{2}$ throw traps. Throw traps were constructed of 5-mm nylon mesh attached to a square metal frame at the bottom and a buoyant PVC frame at the top. Throw traps were placed over the center of each seagrass patch or area of unvegetated sediment, and trapped epifauna were removed with dip nets and preserved in formalin for later processing. Fish and crabs from throw-trap samples were identified to species, and all other crustaceans to family. Seagrass species composition and structure of natural seagrass patches were quantified by taking an additional two cores $(9.8 \mathrm{~cm}$ in diameter) from each patch. Shoot densities, lengths, and widths were averaged from the two cores.

Composition of epifaunal assemblages was compared among treatments (natural seagrass patches, adjacent unvegetated sediments, and artificial shoalgrass and eelgrass patches, sampled at both subtidal and intertidal locations) and between sites using nMDS and randomization tests (ANOSIM and SIMPER) as described above. Variation in total epifaunal abundances was examined with ANOVA, with site as the random factor (two levels: site 1 and 2), and depth (two levels: subtidal and intertidal) and treatment (four levels: natural seagrass, unvegetated habitat, shoalgrass mimic, and eelgrass mimic) as the fixed factors.

\section{Results}

\section{Seagrass species composition}

Shoot density and biomass of Zostera measured in early June decreased over the 19 years of sampling at all sites but one, though the extent of decline varied among sites (site $\times$ year interaction, $F_{20,60}=4.97, P=0.0001$ for density; Fig. $2 ; F_{20,60}=6.15, P=0.00001$ for biomass; results not shown). At four sites (Long Island, Marker 42, Emerald Island Bridge, and Piney Island; Fig. 2), Zostera densities were significantly lower in both the 1990s and 2004 than in 1986 (SNK, at $\alpha=0.05$ ). At these four sites, year-to-year variation among sampling dates in the early 1990s was smaller than longer-term differences between 1986 and the 1990s (Fig. 2). At one site (Huggins Island), densities were highest in 1986, lowest in 2004 and intermediate in the 1990s, but these differences were not statistically significant (SNK tests; Fig. 2).

In contrast with Zostera, June densities (Fig. 2) and biomass (not shown) of Halodule at the same six sites did not show a consistent trend of increase or decrease (site $\times$ year interaction, $F_{20,60}=3.49, P=0.0001$ for density; $F_{20,60}=2.62, P=0.002$ for biomass). At four of the six sites neither shoot density nor biomass significantly differed among years (SNK tests; Fig. 2). At the remaining two sites, densities varied significantly among years, but with no consistent trend (Fig. 2).

In December, the shoot density (Fig. 3) and biomass (not shown) of Zostera was greater in 2004 than on the previous four dates of sampling at three of the sites, although again this pattern was not consistent among sites (site $\times$ year interaction, $F_{16,50}=4.34, P=0.00001$ for density; $F_{16,50}=3.93, P=0.0001$ for biomass) and increasing temporal trends were statistically significant only at one site (SNK tests; Fig. 3). At two of the five sites sampled, Zostera was present only in December 1985 (Piney Island), or was not detected after 1994 (Dog Island). Similar to the June sampling, the December sampling of Halodule did not reveal any consistent 

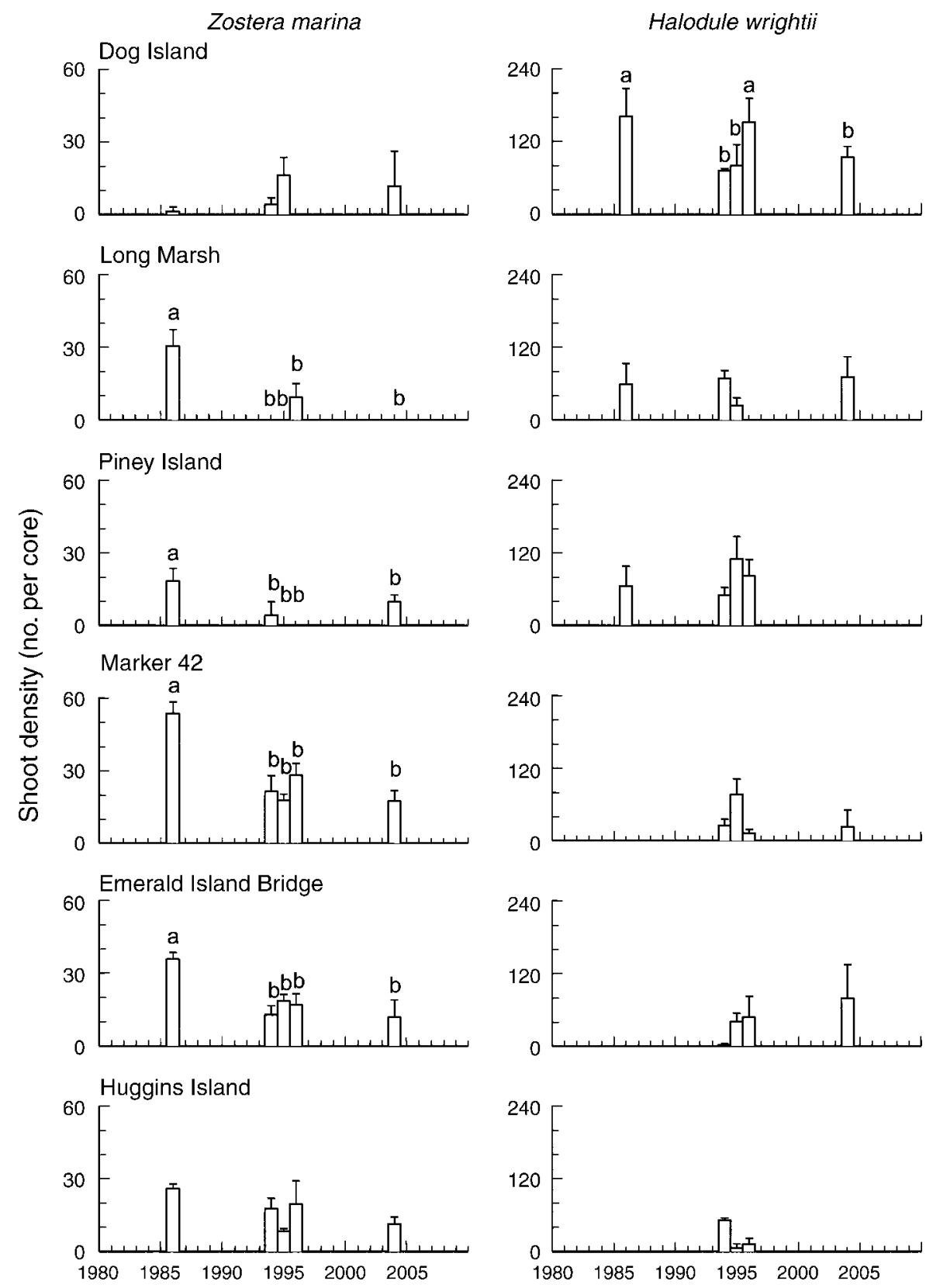

FIG. 2. Shoot density (mean + SE) of Zostera and Halodule in June of 1986, 1994, 1995, 1996, and 2004 at each of six sites sampled within Bogue Sound, North Carolina $(n=3$ cores). Lowercase letters denote groupings, as determined by a posteriori Student-Newman-Keuls tests for significant date $\times$ site interactions $(P<0.05)$.

pattern of change in density (Fig. 3) or biomass (not shown) among the five sites across the two decades of sampling (site $\times$ year interaction, $F_{16,50}=3.51, P=$ 0.0003 for density; $F_{16,50}=2.10, P=0.02$ for biomass). For Halodule densities, even when significant differences among years were detected (i.e., at Dog Island, in both June and December; Figs. 2 and 3), year-to-year variation within sampling periods (the 1980s and the 1990s) was similar to longer-term variation between sampling periods (SNK tests; Figs. 2 and 3).

\section{Sea water temperature and nutrient availability}

Daily mean surface water temperatures in our study area increased by $1.4^{\circ} \mathrm{C}$ between 1985 and 2005. Surface water temperatures exhibited the greatest increases in March and April, and smaller, nonsignificant increases in the other months, with no decreases over the whole time series for any of the months (Table 2). Daily mean temperatures increased by $2.3^{\circ} \mathrm{C}$ in March, and by $2.1^{\circ} \mathrm{C}$ in April (Table 2). 


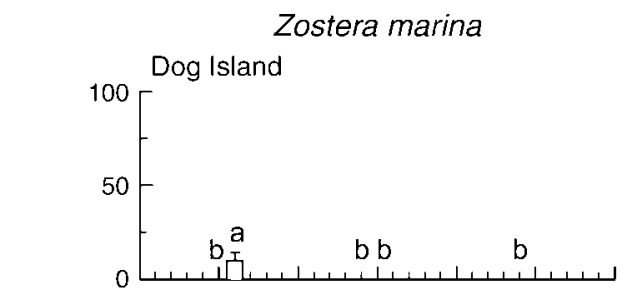

Halodule wrightii
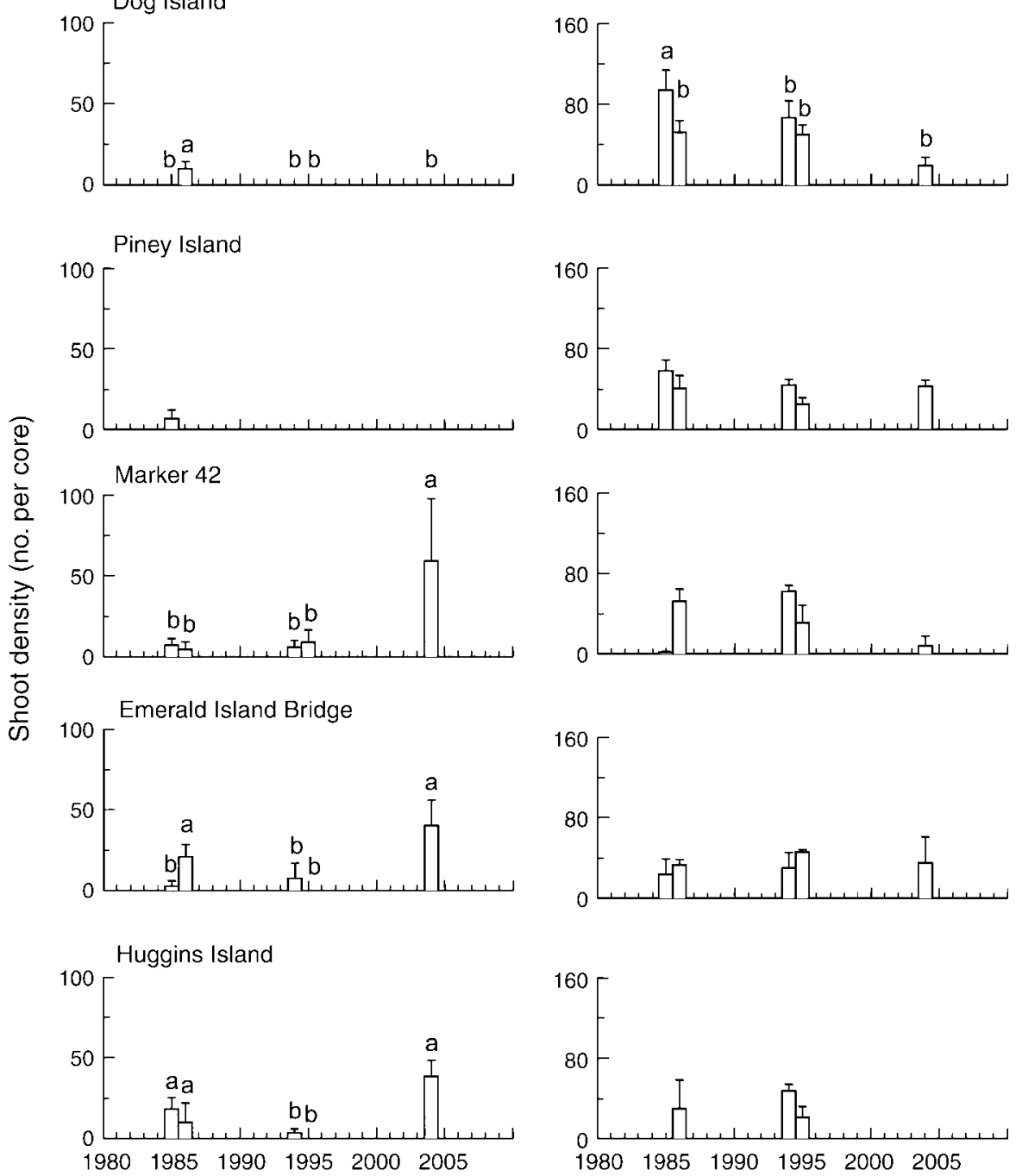

FIG. 3. Shoot density (mean + SE) of Zostera and Halodule in December of 1985, 1986, 1995, 1996, and 2004 at each of five sites sampled within Bogue Sound, North Carolina $(n=3$ cores). Lowercase letters denote groupings, as determined by a posteriori Student-Newman-Keuls tests for significant date $\times$ site interactions $(P<0.05)$.

Water temperature increases appeared to be primarily due to an increase in the daily minimum temperatures (Table 2; Fisher's method of combining probabilities from Spearman's rank correlation; daily minimum temperatures, $P=0.058, n=12$ months; daily maximum temperatures, $P=0.246, n=12$ months). Daily minimum temperatures increased (although not statistically significantly) in nine of the months, with the largest increases in February, March, and May (Table 2). In contrast, daily maximum temperatures increased in six of 12 months. Only in May was this trend towards increases in daily maximum temperatures statistically significant (Spearman's rank correlation, $P=0.008$ ). Thus, significant increase in mean, minimum, and maximum daily temperatures was observed primarily in spring.
Nitrate concentrations in surface waters of the northern part of Bogue Sound (offshore of Morehead City; Fig. 1) increased significantly between the late 1960s and early 1990s, based on comparison of published data (Thayer 1974, Shores 1994). Surface nitrate concentrations measured monthly between September 1967 and September 1968 (range 0.04-1.7 $\mu \mathrm{g} / \mathrm{L}$, $0.5 \pm 0.2 \mu \mathrm{g} / \mathrm{L}[$ mean $\pm \mathrm{SE}]$ ) were significantly lower than concentrations measured between July 1993 and June 1994 (range 1.7-9.3 $\mu \mathrm{g} / \mathrm{L}, 4.5 \pm 0.8 \mu \mathrm{g} / \mathrm{L}$ [mean \pm $\mathrm{SE}] ; t=5.0, \mathrm{df}=21, P<0.001)$. Values reported for 1993-1994 by Shores (1994) were similar to concentrations that we measured at four different locations within Bogue Sound during the following year. Nitrate concentrations in surface waters in 1995 ranged 2.0$3.1 \mu \mathrm{g} / \mathrm{L}$ on the July sampling date, and $6.5-6.8 \mu \mathrm{g} / \mathrm{L}$ in 
TABLE 2. Increases or decreases, by month, in daily average and minimum and maximum temperatures of surface waters in Back Sound, North Carolina, between 1985 and 2005.

\begin{tabular}{lccc}
\hline \hline \multirow{2}{*}{ Month } & \multicolumn{2}{c}{ Temperature change $\left({ }^{\circ} \mathrm{C}\right), 1985-2005$} \\
\cline { 2 - 4 } & Daily average & Daily minimum & Daily maximum \\
\hline January & 0.01 & 0.77 & -0.36 \\
February & 0.75 & 3.15 & 2.22 \\
March & 2.27 & 1.67 & 0.94 \\
April & 2.08 & 0.93 & 0.56 \\
May & 1.09 & 1.50 & 1.09 \\
June & 1.23 & 0.29 & -0.32 \\
July & 0.41 & -0.05 & -0.23 \\
August & 0.87 & 0.59 & 0.68 \\
September & 0.33 & 0.63 & -0.03 \\
October & 1.65 & -1.62 & -1.93 \\
November & 0.69 & -3.09 & -3.47 \\
December & 1.10 & 0.91 & -0.91 \\
\hline
\end{tabular}

Note: Temperature changes were determined by linear regression of monthly averages of each variable across the 20 years.

August (24 hours after a rainstorm event). Variation across the sites was not significant (ANOVA, $F_{3,18}=0.6$, $P>0.05)$. Phosphate concentrations ranged $18-23 \mu \mathrm{g} / \mathrm{L}$ in July, and 26-33 $\mu \mathrm{g} / \mathrm{L}$ in August 1995. On both dates, phosphate concentrations were slightly greater at one of the sites compared to the other three (ANOVA, $F_{3,18}=$ 4.6, $P<0.05)$.

\section{Seagrass transplant experiments}

Shoot densities of transplanted seagrass declined over the 6-month duration of the experiments, although the rate and between-habitat variation of this decline varied significantly between the two species. Following transplantation of Zostera into seagrass beds and unvegetated sediments at intertidal and subtidal depths, the shoot density of seagrass plugs rapidly declined (Table 3, Fig. 4). This decline was particularly severe in unvegetated sediments where, after 1 month, Zostera shoots exhibited less than one-third their initial density and, in subsequent months, Zostera was completely eliminated. The only exception to this rapid decline was observed in subtidal seagrass beds at site 1 , where shoot density of Zostera plugs increased following the initial disturbance of transplantation such that, 6 months after transplantation, shoot density of plugs was indistinguishable from initial transplant density, suggesting that the decline observed in the other habitat types was not due to the transplant disturbance itself (Fig. 4). Differences in Zostera densities of transplanted seagrass plugs among habitats mirrored those of background grass densities (Fig. 4).

In contrast with Zostera, Halodule plugs declined in density immediately following transplantation only when transplanted into intertidal unvegetated sediments, and this decline was statistically significant only at site 1 (Table 3, Fig. 5). Three months after transplantation, Halodule plugs transplanted into intertidal and subtidal seagrass beds at site 1, and into intertidal beds and subtidal sand at site 2 , had greater shoot densities than in other habitat types (SNK tests; Fig. 5). Even 6 months after transplantation, live Halodule shoots remained in all habitats, including in unvegetated subtidal flats, with one exception, intertidal sand (Fig. 5). In contrast to the patterns exhibited in transplant plugs, natural densities of Halodule were greater on all dates in intertidal beds than in the other habitats, and small amounts of Halodule were occasionally found in subtidal beds, but never in the intertidal or subtidal sand flats.

\section{Relative value of eelgrass and shoalgrass in habitat provision}

Comparisons of seagrass species composition among seagrass beds located at varying depths indicated that, as expected, Zostera densities increased with depth, whereas the opposite was true for Halodule (Table 4). Zostera was not present (site 1, October) or had low densities (in May at site 1 and in both sampling dates at site 2) in intertidal beds, which were instead dominated by Halodule. Conversely, Halodule was absent (site 1) or found at low densities (site 2) in deeper subtidal seagrass beds (Table 4). Also as expected, Halodule was denser in October than May, whereas the opposite pattern was exhibited by Zostera. Zostera blades were on average twice as long in May as in October. In contrast, Halodule blade lengths did not vary seasonally (Table 4). Thus, structural characteristics of seagrass beds varied significantly with depth and through time, depending on the relative dominance and seasonal growth of the two seagrass species.

The structure of invertebrate assemblages varied significantly among seagrass beds located at different depths and dominated by Zostera $(\mathrm{Z})$, Halodule $(\mathrm{H})$, or a mixture (M) of these two species (ANOSIM; October, $R$ $=0.20, P=0.001$; May, $R=0.25, P=0.001)$, and

TABLE 3. ANOVAs testing for change in shoot density of seagrass plugs transplanted into intertidal and subtidal habitats at two sites in Middle Marsh, North Carolina

\begin{tabular}{lrrrrrr}
\hline \hline & & \multicolumn{2}{c}{$\begin{array}{c}\text { Zostera } \\
\text { transplants }\end{array}$} & & \multicolumn{2}{c}{$\begin{array}{c}\text { Halodule } \\
\text { transplants }\end{array}$} \\
\cline { 3 - 4 } \cline { 6 - 7 } Source & df & \multicolumn{1}{c}{ MS } & \multicolumn{1}{c}{$F$} & & MS & $F$ \\
\hline $\mathrm{Ti}$ & 3 & 613.64 & 4.01 & & 42.82 & $80.52^{* *}$ \\
$\mathrm{Tr}$ & 3 & 70.42 & $21.21^{*}$ & & 17.68 & 4.61 \\
$\mathrm{Si}$ & 1 & 74.11 & $26.08^{* * *}$ & & 0.20 & 0.25 \\
$\mathrm{Ti} \times \mathrm{Tr}$ & 9 & 9.71 & 0.72 & & 3.68 & 2.35 \\
$\mathrm{Ti} \times \mathrm{Si}$ & 3 & 153.09 & $53.87^{* * *}$ & & 0.53 & 0.66 \\
$\mathrm{Tr} \times \mathrm{Si}$ & 3 & 3.32 & 1.17 & & 3.84 & $4.77^{* *}$ \\
$\mathrm{Ti} \times \mathrm{Tr} \times \mathrm{Si}$ & 9 & $\mathbf{1 3 . 5 4}$ & $\mathbf{4 . 7 6 * * *}$ & & $\mathbf{1 . 5 6}$ & $\mathbf{1 . 9 4}$ \\
Residual & 288 & 2.84 & & & 0.80 & \\
\hline
\end{tabular}

Notes: $\mathrm{Ti}=$ time (fixed, four levels: $0,1,3$, and 6 months after transplant), $\operatorname{Tr}=$ treatment (fixed, four levels: intertidal seagrass, intertidal sandflat, subtidal seagrass, subtidal sandflat), $\mathrm{Si}=$ site (random, two levels); $n=10$ seagrass plugs. Significant terms that were examined further using SNK tests (see Appendix A) are shown in bold. Zostera data were not transformed; Halodule data were $\log (x+1)$-transformed. Cochran's test results were: Zostera, $C=0.083, P<0.05$; Halodule, $C=0.087, P<0.05)$.

* $P<0.05 ; * * P<0.01 ; * * * P<0.001$. 
Transplant

Intertidal seagrass bed

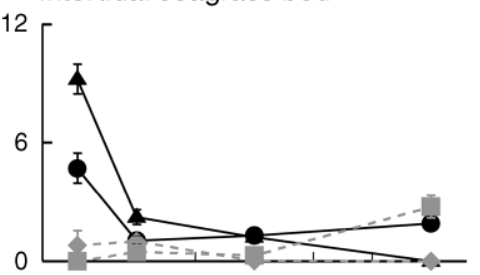

Intertidal sand

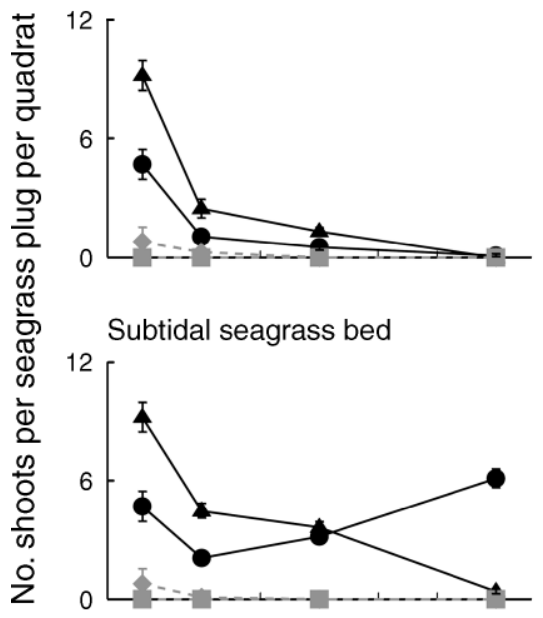

Subtidal sand

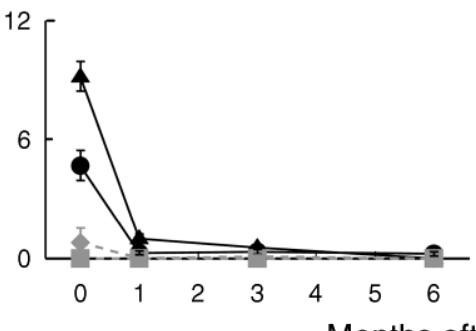

Natural seagrass
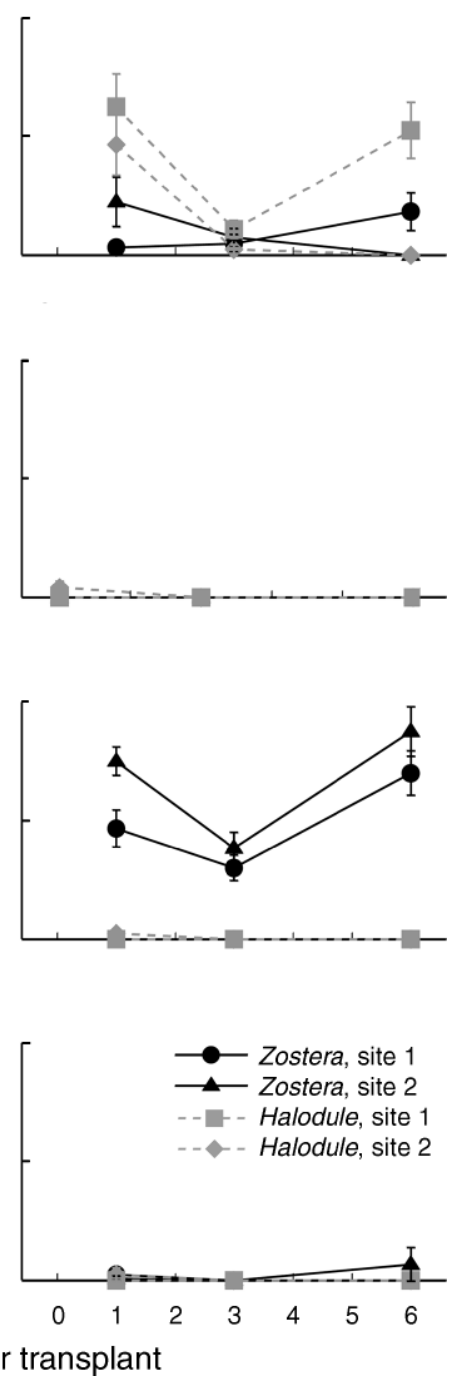

FIG. 4. Shoot density (mean $\pm \mathrm{SE}$ ) of transplanted Zostera plugs for each natural habitat to which plugs were transplanted. Densities are shown at time of transplantation and 1,3 , and 6 months after transplant; $n=40$ seagrass plugs.

between sites (ANOSIM; October, $R=0.18, P=0.003$; May, $R=0.50, P=0.001$ ). In both sampling periods, Zostera (i.e., deeper subtidal) and mixed-species (shallow subtidal) beds were the least dissimilar from one another (October, $\mathrm{Z}$ vs. $\mathrm{M}, R=0.11, \mathrm{Z}$ vs. $\mathrm{H}, R=0.17$, $\mathrm{H}$ vs. $\mathrm{M}, R=0.31$; May, $\mathrm{Z}$ vs. $\mathrm{M}, R=0.17$, $\mathrm{Z}$ vs. $\mathrm{H}, R=$ 0.34 , $\mathrm{H}$ vs. $\mathrm{M}, R=0.25$ ), whereas Halodule (intertidal) beds exhibited greater dissimilarity from the other seagrass bed types (Fig. 6). In October, 10 taxa accounted for $50 \%$ of overall dissimilarity between seagrass bed types, seven of these consistently across samples, i.e., with relatively high ratios $(>1)$ between mean dissimilarity among seagrass bed types and variability in dissimilarity values (Table 5). All seven taxa had greater abundances either in Zostera or mixedspecies than in Halodule beds, with abundances of spionid, nereid, capitellid, and arabellid polychaetes, of the gastropod Bittium varium, and of gammarid amphipods ranking highest in mixed-species beds, and maldanid polychaetes having greatest abundances in Zostera beds (Table 5). In May, six taxa accounted for $50 \%$ of overall dissimilarity between seagrass bed types (Table 5). Similar to the October sampling, most of the discriminating taxa had lowest abundances in Halodule beds, except for nereid and arabellid polychaetes, which ranked lowest in mixed-species beds (Table 5).

Differences among depths in total invertebrate abundances (no. individuals/core), invertebrate diversity, measured as the number of families identified in the cores, and total infaunal and epifaunal abundances varied between sites and with sampling date (Table 6, Figs. 7 and 8). When significant differences among 
Transplant

Intertidal seagrass bed

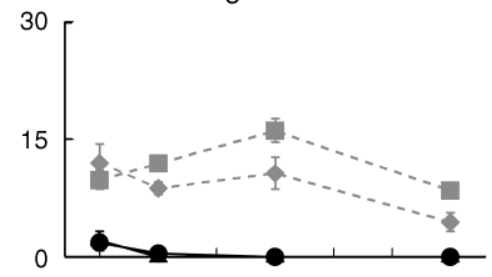

Intertidal sand

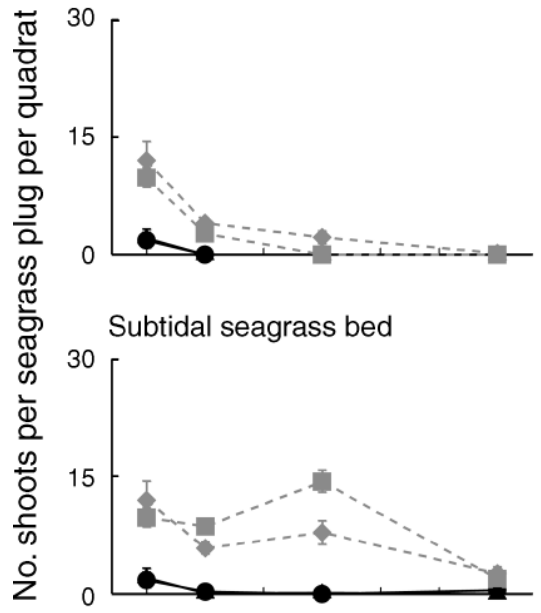

Subtidal sand

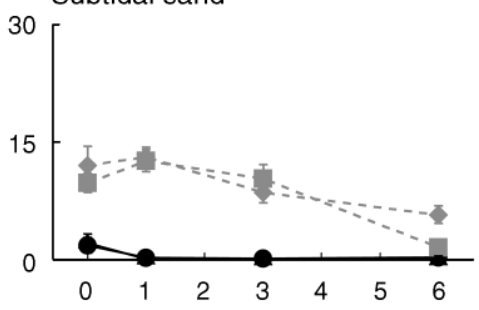

Natural seagrass
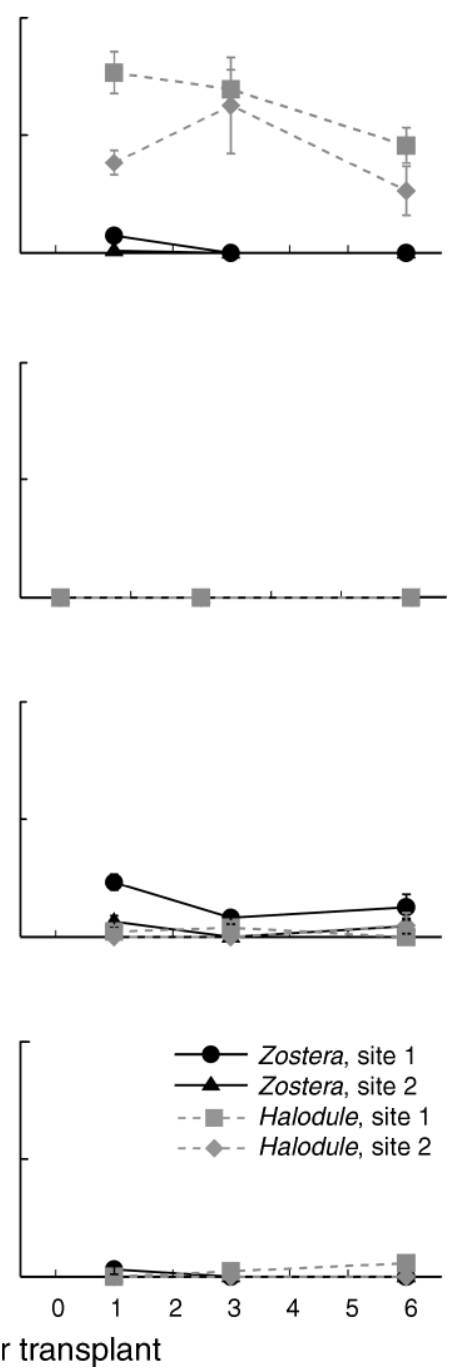

FIG. 5. Shoot density (mean $\pm \mathrm{SE}$ ) of transplanted Halodule plugs for each natural habitat to which plugs were transplanted. Densities are shown at time of transplantation and 1,3, and 6 months after transplant; $n=40$ seagrass plugs.

depths were found, these tended to consist of deep and intermediate habitats having significantly greater abundances and diversity than intertidal habitats, with the exception of site 2 in May, where deep and intertidal habitats ranked highest (SNK tests; Table 6, Figs. 7 and 8). For both total abundance and abundances separated into infaunal and epifaunal groups, there was also a significant interaction between depth and habitat type (Table 6, Fig. 7). In all cases, seagrass beds at deep (Zostera-dominated) and intermediate (mixed species) locations had significantly greater abundances than intertidal, Halodule-dominated seagrass beds. In contrast, abundances were not significantly different among depths for unvegetated habitats (SNK tests; Table 6).

The short-term (2-month duration) colonization experiment of artificial seagrass mimics revealed that structural differences among seagrass patches can have significant effects on epifaunal assemblages, although effects were not general. Distinct epifaunal assemblages also colonized structurally identical seagrass mimics deployed at different depths. Thus, both structural characteristics and depth determine the quality of seagrass as habitat for epibenthic organisms.

The structure of assemblages varied significantly among experimental treatments (ANOSIM, $R=0.67$, $P=0.001$ ) and between sites (ANOSIM, $R=0.71, P=$ 0.001). Pairwise comparisons showed that all treatments hosted significantly different epifaunal assemblages $(R=$ $0.42-1.0, P=0.008-0.001$ ), with the exception of Halodule and Zostera mimics deployed at the same depth (intertidal, $R=0.27, P=0.06$; subtidal, $R=0.18$, $P=0.08)$. This result suggests that seagrass structural 
TABLE 4. Species composition and structural characteristics of the Zostera marina (deeper subtidal), Halodule wrightii (intertidal), and mixed-species (shallow subtidal) seagrass beds where invertebrates were sampled.

\begin{tabular}{|c|c|c|c|c|}
\hline \multirow{2}{*}{$\begin{array}{l}\text { Bed type and season, } \\
\text { by site }\end{array}$} & \multicolumn{2}{|c|}{ No. shoots/core } & \multicolumn{2}{|c|}{ Blade length $(\mathrm{cm})$} \\
\hline & Halodule & Zostera & Halodule & Zostera \\
\hline \multicolumn{5}{|l|}{ Site 1} \\
\hline \multicolumn{5}{|l|}{ Halodule (shallow) } \\
\hline Fall & $20.9(3.5)$ & $0.0(0.0)$ & $8.6(0.6)$ & nd \\
\hline Spring & $11.5(1.4)$ & $2.1(1.2)$ & $7.6(0.4)$ & $15.4(1.7)$ \\
\hline \multicolumn{5}{|l|}{ Mixed (intermediate) } \\
\hline Fall & $9.3(2.2)$ & $2.5(0.6)$ & $6.4(0.8)$ & $7.7(0.9)$ \\
\hline Spring & $3.1(1.1)$ & $11.2(1.9)$ & $6.8(0.5)$ & $15.1(0.9)$ \\
\hline \multicolumn{5}{|l|}{ Zostera (deep) } \\
\hline Fall & $0.0(0.0)$ & $5.4(0.8)$ & nd & $11.4(0.8)$ \\
\hline Spring & $0.0(0.0)$ & $17.8(1.6)$ & nd & $15.3(0.7)$ \\
\hline \multicolumn{5}{|l|}{ Site 2} \\
\hline \multicolumn{5}{|l|}{ Halodule (shallow) } \\
\hline Fall & $17.7(4.2)$ & $1.1(0.6)$ & $6.8(0.3)$ & nd \\
\hline Spring & $14.2(2.7)$ & $2.4(1.2)$ & $5.8(0.3)$ & $11.3(2.5)$ \\
\hline \multicolumn{5}{|l|}{ Mixed (intermediate) } \\
\hline Fall & $9.9(2.0)$ & $5.1(1.6)$ & $6.1(0.4)$ & $7.6(0.7)$ \\
\hline Spring & $11.6(4.1)$ & $12.6(1.2)$ & $6.9(0.7)$ & $12.3(0.9)$ \\
\hline \multicolumn{5}{|l|}{ Zostera (deep) } \\
\hline Fall & $0.9(0.8)$ & $10.7(0.9)$ & $7.0(0.2)$ & $6.5(0.7)$ \\
\hline Spring & $0.0(0.0)$ & $5.0(0.8)$ & nd & $15.0(1.2)$ \\
\hline
\end{tabular}

Notes: Invertebrates were sampled using 10 replicate $9.8 \mathrm{~cm}$ diameter cores in fall (October 1992) and spring (May 1993). One seagrass bed of each type was sampled at each of two sites in Middle Marsh, North Carolina. Means (with SE in parentheses) are reported. The lengths of the longest blades in up to five seagrass shoots of each species, within each core, were measured. Zostera or Halodule shoots were not present in some of the seagrass by date of sampling combinations, and blade lengths could not be determined (nd).

A) Site 1, October 1992

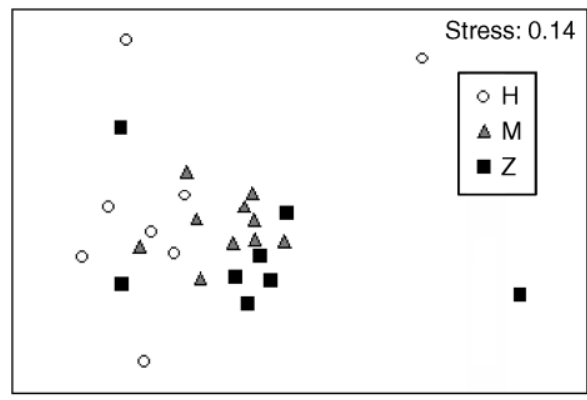

C) Site 1, May 1993

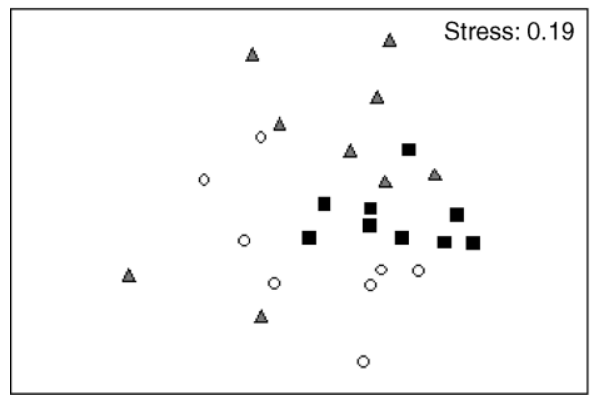

B) Site 2, October 1992

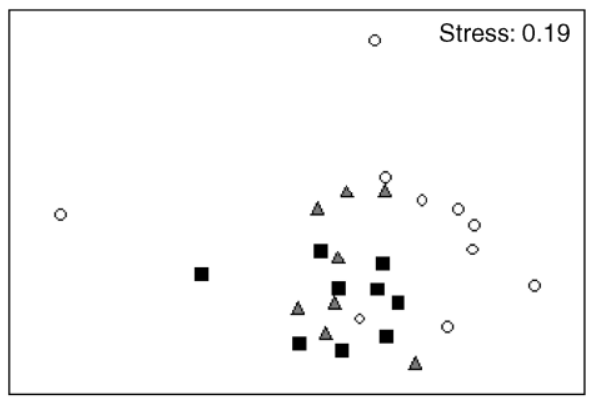

D) Site 2, May 1993

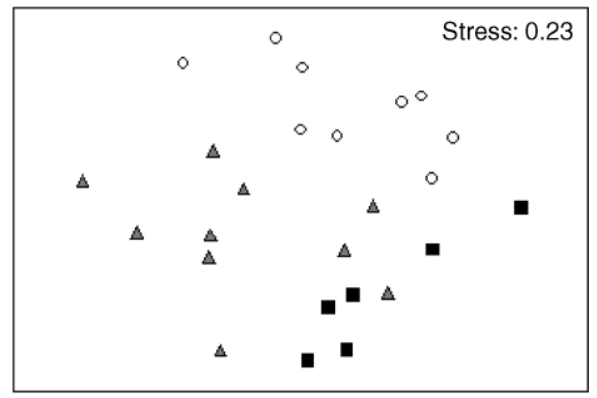

FIG. 6. Ordinations (nonmetric multidimensional scaling, nMDS) of relative similarities between benthic invertebrate assemblages from Halodule (H), Zostera (Z), and mixed-species (M) seagrass beds sampled in (A, B) October 1992 and (C, D) May 1993 at sites 1 (A, C) and 2 (B, D) within Middle Marsh, North Carolina. Abundance data (no. individuals/core) of taxa from 8-10 cores for each treatment combination were used to calculate similarity values. 
TABLE 5. Results of SIMPER analyses showing taxa characterizing different seagrass bed types (deeper-subtidal seagrass beds, dominated by Zostera marina, Z; shallow-subtidal beds containing mixtures of $Z$. marina and Halodule wrightii, $\mathrm{M}$; and intertidal beds dominated by H. wrightii, $\mathrm{H})$.

\begin{tabular}{|c|c|c|c|c|c|c|}
\hline \multirow[b]{2}{*}{ Taxa } & \multicolumn{6}{|c|}{ Mean no. individuals per core, by bed type } \\
\hline & $\mathrm{Z}$ & M & $\mathrm{H}$ & $\mathrm{Z}$ vs. $\mathrm{M}$ & $\mathrm{Z}$ vs. $\mathrm{H}$ & $\mathrm{M}$ vs. $\mathrm{H}$ \\
\hline \multicolumn{7}{|l|}{ A) October 1992} \\
\hline Spionidae $\dagger$ & 4.2 & 8.6 & 1.5 & 9.3 & 8.6 & 11.4 \\
\hline Bittium varium $\dagger$ & 3.9 & 4.2 & 0.4 & 8.1 & 8.1 & 8.0 \\
\hline Nereidae $\dagger$ & 2.5 & 2.7 & 1.2 & 5.5 & 7.4 & 7.1 \\
\hline Capitellidae $\dagger$ & 2.0 & 2.8 & 0.9 & 5.5 & 6.5 & 7.0 \\
\hline Arabellidae $\dagger$ & 1.3 & 1.4 & 0.5 & 5.0 & 4.7 & 5.1 \\
\hline Maldanidae $\dagger$ & 1.1 & 0.2 & 0.2 & 3.6 & 4.2 & 2.0 \\
\hline Eunicidae & 1.1 & 0.4 & 0.6 & 3.3 & 4.1 & 3.4 \\
\hline Onuphidae & 0.8 & 0.1 & 0.2 & 2.9 & 3.7 & 1.5 \\
\hline Gammarid amphipods & 0.7 & 4.0 & 0.2 & 8.9 & 3.2 & 9.8 \\
\hline Ampharetidae & 0.5 & 0.2 & 0.3 & 2.6 & 3.3 & 2.0 \\
\hline \multicolumn{7}{|l|}{ B) May 1993} \\
\hline Capitellidae $\dagger$ & 7.4 & 3.1 & 2.9 & 9.7 & 11.0 & 9.2 \\
\hline Spionidae $\dagger$ & 6.9 & 7.5 & 4.0 & 9.7 & 8.6 & 9.7 \\
\hline Arabellidae $\dagger$ & 4.1 & 1.6 & 3.2 & 9.3 & 11.4 & 10.4 \\
\hline Nereidae $\dagger$ & 2.7 & 1.0 & 1.4 & 7.6 & 10.0 & 8.0 \\
\hline Maldanidae $\dagger$ & 1.7 & 1.4 & 1.0 & 7.0 & 7.4 & 6.9 \\
\hline Gammarid amphipods $\uparrow$ & 1.5 & 1.4 & 0.4 & 5.7 & 6.6 & 6.7 \\
\hline \multicolumn{7}{|c|}{$\begin{array}{l}\text { Notes: Numbers of individuals per core were averaged over the } 8-10 \text { cores collected at each of } \\
\text { two sites within each seagrass bed type }(\mathrm{Z}, \mathrm{M} \text {, and } \mathrm{H}) \text { for each sampling date (October and May). } \\
\text { Percentage contributions to dissimilarity between pairs of seagrass bed types ( } \mathrm{Z} \text { vs. M, Z vs. H, and } \\
\mathrm{M} \text { vs. H) are also given for each of the taxa. Percentage contributions to dissimilarity cumulatively } \\
\text { accounting for } 50 \% \text { of overall dissimilarity between pairs of seagrass bed types are reported in bold. } \\
\quad \dagger \text { The best discriminating taxa, i.e., those with ratios of dissimilarity over standard deviation } \\
\text { equal or greater than } 1 \text { (see Methods: Relative value of eelgrass and shoalgrass in habitat provision). }\end{array}$} \\
\hline
\end{tabular}

differences alone do not influence epifaunal community structure.

All taxa were significantly more abundant in structural habitat, either natural or artificial, than in unvegetated bottoms, with the exception of spot,
Leiostomus xanthurus (the species accounting for $55.7 \%$ of all fish collected at the end of this experiment, $n=494$ individuals), which was most abundant in deep unvegetated habitat (Table 7). Variation among structural habitat was observed only for comparisons

TABLE 6. ANOVAs testing for differences in total invertebrate abundances, number of invertebrate families, and total infaunal and epifaunal abundances from benthic cores collected at different depths and within both vegetated and unvegetated habitats.

\begin{tabular}{|c|c|c|c|c|c|c|c|c|c|}
\hline \multirow[b]{2}{*}{ Source } & \multirow[b]{2}{*}{$\mathrm{df}$} & \multicolumn{2}{|c|}{ Total abundance } & \multicolumn{2}{|c|}{ No. families } & \multicolumn{2}{|c|}{ Infaunal abundance } & \multicolumn{2}{|c|}{ Epifaunal abundance } \\
\hline & & MS & $F$ & MS & $F$ & MS & $F$ & MS & $F$ \\
\hline $\mathrm{Si}$ & 1 & 10.7 & $21.6^{* * *}$ & 2.1 & $7.4^{* *}$ & 9.9 & $21.0 * * *$ & 2.3 & $4.2 *$ \\
\hline $\mathrm{De}$ & 2 & 3.2 & 8.9 & 1.2 & 15.9 & 1.8 & 2.7 & 7.0 & $76.5^{*}$ \\
\hline $\mathrm{Ha}$ & 1 & 50.6 & 47.9 & 21.6 & 68.4 & 39.1 & 19.7 & 53.9 & 32.6 \\
\hline $\mathrm{Ti}$ & 1 & 10.8 & 62.8 & 0.7 & 2.2 & 18.8 & 21.8 & 4.0 & 2.2 \\
\hline $\mathrm{Si} \times \mathrm{De}$ & 2 & 0.4 & 0.7 & 0.1 & 0.3 & 0.7 & 1.4 & 0.1 & 0.2 \\
\hline $\mathrm{Si} \times \mathrm{Ha}$ & 1 & 1.1 & 2.1 & 0.3 & 1.1 & 2.0 & $4.2^{*}$ & 1.6 & 3.0 \\
\hline $\mathrm{Si} \times \mathrm{Ti}$ & 1 & 0.2 & 0.3 & 0.3 & 1.2 & 0.9 & 1.8 & 1.8 & 3.4 \\
\hline $\mathrm{De} \times \mathrm{Ha}$ & 2 & 2.9 & $19.9 *$ & 0.8 & 3.6 & 1.6 & $21.4^{*}$ & 6.7 & $119.1^{* *}$ \\
\hline $\mathrm{De} \times \mathrm{Ti}$ & 2 & 2.0 & 0.4 & 0.3 & 0.2 & 1.6 & 0.3 & 1.7 & 1.9 \\
\hline $\mathrm{Ha} \times \mathrm{Ti}$ & 1 & 1.8 & 2.6 & 1.2 & 10.7 & 0.9 & 0.7 & 0.01 & 0.1 \\
\hline $\mathrm{Si} \times \mathrm{De} \times \mathrm{Ha}$ & 2 & 0.1 & 0.3 & 0.2 & 0.8 & 0.1 & 0.2 & 0.1 & 0.1 \\
\hline $\mathrm{Si} \times \mathrm{De} \times \mathrm{Ti}$ & 2 & 4.8 & $9.7 * * *$ & 1.8 & $6.5^{* *}$ & 5.0 & $10.6^{* * *}$ & 0.9 & 1.6 \\
\hline $\mathrm{Si} \times \mathrm{Ha} \times \mathrm{Ti}$ & 1 & 0.7 & 1.4 & 0.1 & 0.4 & 1.3 & 2.7 & 0.1 & 0.1 \\
\hline $\mathrm{De} \times \mathrm{Ha} \times \mathrm{Ti}$ & 2 & 0.6 & 0.8 & 0.3 & 0.8 & 0.3 & 0.3 & 0.4 & 12.6 \\
\hline $\mathrm{Si} \times \mathrm{De} \times \mathrm{Ha} \times \mathrm{Ti}$ & 2 & 0.7 & 1.4 & 0.4 & 1.3 & 1.0 & 2.1 & 0.03 & 0.1 \\
\hline Residual & 168 & 0.5 & & 0.3 & & 0.5 & & 0.5 & \\
\hline
\end{tabular}

Notes: $\mathrm{Si}=$ site (random, two levels), $\mathrm{De}=$ depth (fixed, three levels: deeper subtidal [D], shallow subtidal [S], and intertidal [I]), $\mathrm{Ha}=$ habitat (fixed, two levels: vegetated and unvegetated), and $\mathrm{Ti}=$ time (fixed, two levels: October and May sampling); $n=8$ cores. Significant terms that were examined further using SNK tests (see Appendix B) are shown in bold. All data were log $(x+1)-$ transformed. Cochran's test results were: total abundance, $C=0.15, P<0.01$; number of families, $C=0.11$, ns $(P>0.05)$; infaunal abundance, $C=0.12$, ns $(P>0.05)$; epifaunal abundance, $C=0.14, P<0.05$.

$* P<0.05 ; * * P<0.01 ; * * * P<0.001$ 


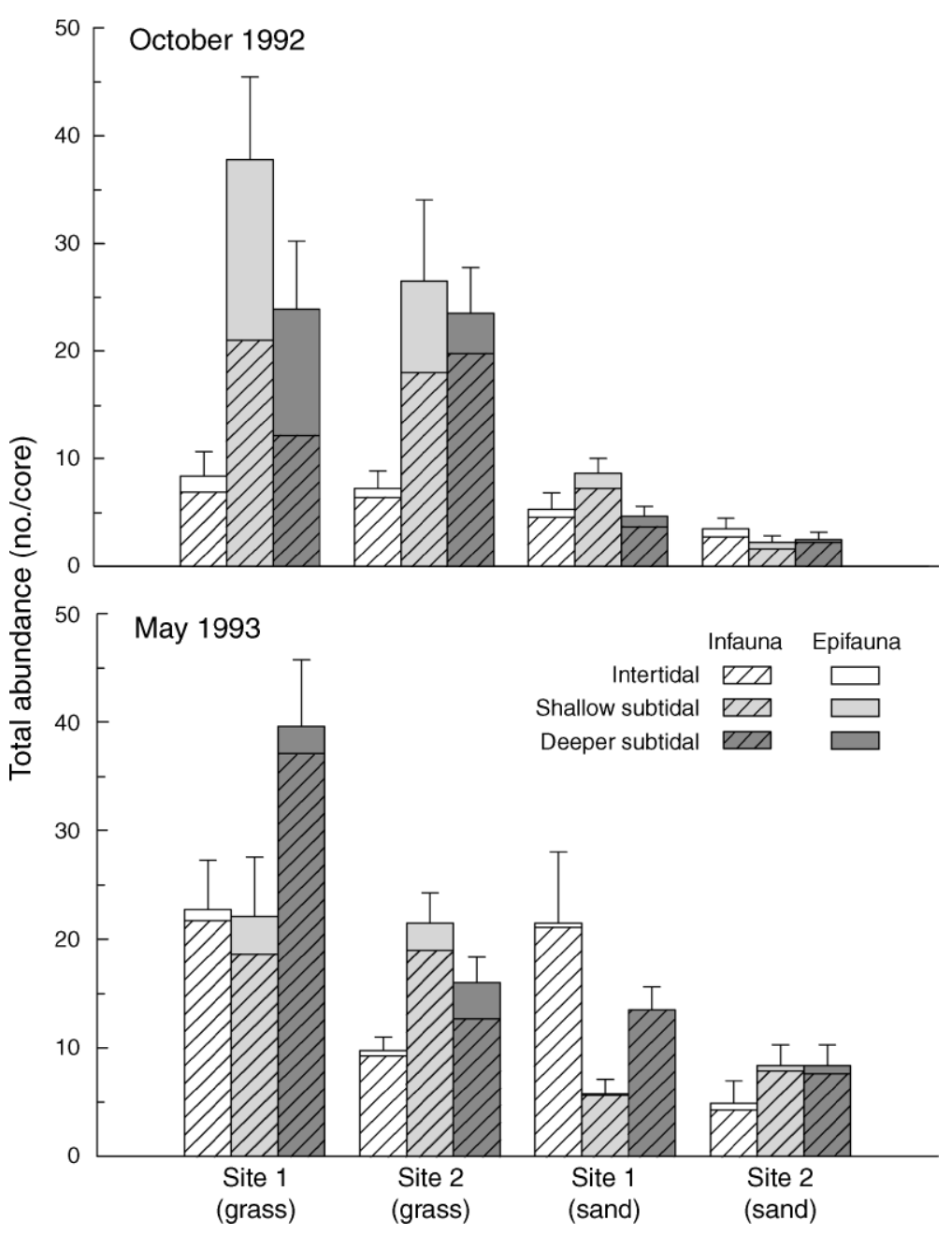

FIG. 7. Abundance (no. individuals/core, mean + SE) of invertebrates in seagrass beds and unvegetated habitat at intertidal (Halodule-dominated), shallow-subtidal (mixed-species), and deeper subtidal (Zostera-dominated) locations; $n=10$ cores.

between natural and artificial seagrass, but not between seagrass mimics with different structural characteristics, unless these were deployed at different depths. Amphipods, shrimp, and the pinfish Lagodon rhomboides (27.5\% of all fish) tended to be more abundant in natural than artificial Zostera, whereas the blue crab Callinectes sapidus was twice as abundant in artificial than in natural Zostera (Table 7). Amphipods and shrimp were also more abundant in artificial than natural Halodule patches, and explained over half of the between-depth variation in assemblages from seagrass mimics (Table 7). Trends were similar for both Halodule and Zostera mimics, with amphipods being more abundant at intertidal and shrimp at deep locations (Table 7).

In contrast with epifaunal community structure, total epifaunal abundances did vary between seagrass mimics with different structural characteristics, but only at intertidal locations and at one of the two sites where the experiment was replicated (Table 8; Fig. 9). At intertidal locations of site 1, Zostera mimics had the highest epifaunal abundances, unvegetated habitat had the lowest, and natural Halodule and Halodule mimics were intermediate and not significantly different from each other (SNK; Fig. 9). However, this pattern was not observed at the other depth $\times$ site combinations $(\mathrm{SNK}$; Fig. 9).

\section{DisCUSSION}

A growing number of studies point to worldwide decline in seagrasses as a result of local anthropogenic impacts and global change (reviewed by Duarte 2002). Along the Gulf Coast of Florida and in Long Island Sound, Connecticut, abundances of deep-dwelling species of seagrass have declined following increases in nutrient loading, which enhances phytoplankton abundance and decreases water clarity (Keser et al. 2003, Hale et al. 2004). Interannual changes in the growth of Posidonia oceanica along the Spanish Mediterranean coast between 1967 and 1992 exhibited significant 


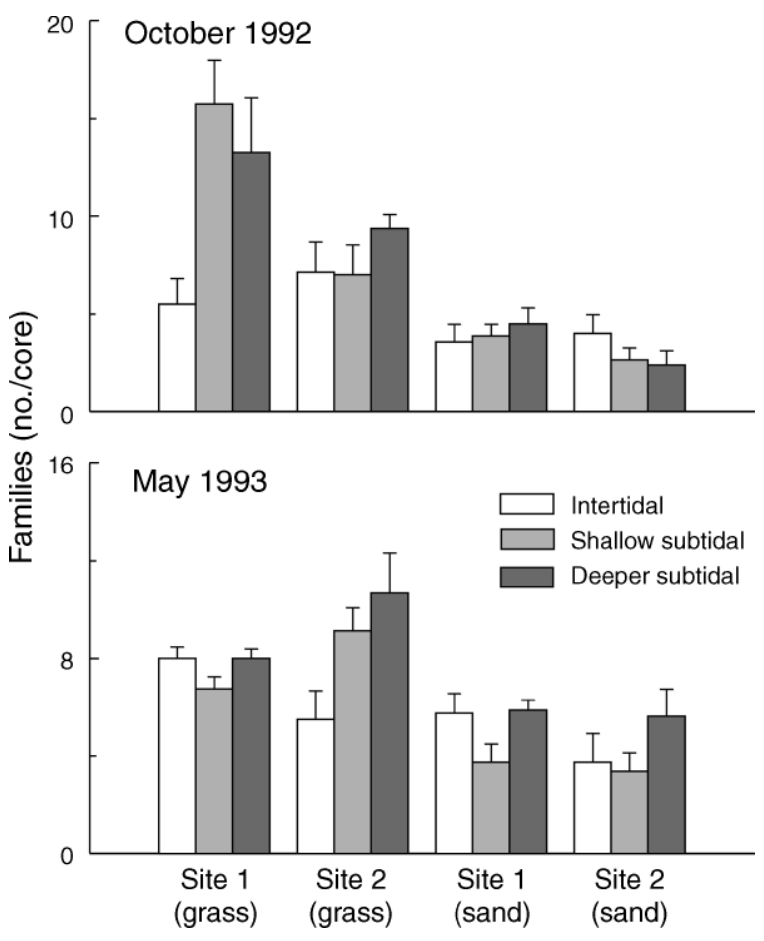

FIG. 8. Number of invertebrate families per core (mean + SE) in seagrass beds and unvegetated sand at intertidal (Halodule-dominated), shallow-subtidal (mixed-species), and deeper subtidal (Zoster $a$-dominated) locations; $n=10$ cores.

coupling with climate variability (Marbà and Duarte 1997), and the gradual decline of Zostera marina in the 1980s and 1990s along the Atlantic French coast was related to elevated sea-surface temperatures beginning in the 1980s (Glémarec 1997). Our sampling of coastal North Carolina lagoons over the past 19 years similarly suggests that alteration of seagrass habitat has occurred, coincident with environmental change, with important implications for the provision of habitat to macroinvertebrates and fishes.
Monitoring of mixed-species seagrass beds of Zostera marina and Halodule wrightii between 1985 and 2004 at a natural ecotone between temperate and tropical seagrass beds revealed changes in seagrass composition coincident with warming of spring temperatures and possibly increased anthropogenic nutrient loading. Summer abundance of the temperate, deeper-dwelling species, Zostera marina, decreased, whereas no change in the abundance of the tropical and shallower species Halodule wrightii occurred in summer or winter.

Between 1985 and 2005, mean daily water temperatures increased by $1.4^{\circ} \mathrm{C}$ in our study area, an increase that is slightly greater than what has been observed to the north in Woods Hole, Massachusetts, USA, where long-term sea surface temperature series have shown that an average warming of $1.2^{\circ} \mathrm{C}$ over 30 years, from 1970 to 2002 (Nixon et al. 2004). Mean daily surface water temperatures were slightly warmer in every month, though this increase was statistically significant only in spring, the prime growing season of Z. marina, when mean daily temperature increased by up to $2.3^{\circ} \mathrm{C}$ over the last two decades (Table 2).

Nitrate concentrations in surface waters of Bogue Sound (Thayer 1974, Shores 1994) increased significantly between the late 1960s and early 1990s, suggesting that nutrient loading to this water body may have increased. Concentrations reported for 1993-1994 (Shores 1994) were similar to measurements that we made at additional locations in 1995, suggesting that values reported for one location (offshore of Morehead City) may be representative of Bogue Sound waters. Mesocosm experiments previously conducted in our study region (Burkholder et al. 1992, 1994) indicate that high nitrogen concentrations have negative effects on the seagrass species Zostera marina, Thalassia testudinum, and Syringodium filiforme, but not on Halodule wrightii and Ruppia maritima. However, nutrient concentration measurements repeated in Bogue Sound in the late 1960s and early 1990s (Thayer 1974, Shores 1994), and our measurements in 1995 reveal that nitrate concentrations, even after rainstorm events,

TABLE 7. Results of SIMPER analyses showing epifaunal taxa characterizing unvegetated habitat (UV), natural seagrass patches (dominated by Halodule [H], at intertidal locations, or by Zostera [Z], at subtidal locations), and Halodule (HM) and Zostera (ZM) mimics at each of two depths, intertidal (I) and subtidal (S).

\begin{tabular}{|c|c|c|c|c|c|c|c|c|c|c|c|c|c|}
\hline \multirow[b]{3}{*}{ Taxa } & \multicolumn{8}{|c|}{ No. individuals $/ \mathrm{m}^{2}$} & \multicolumn{5}{|c|}{ Contribution to dissimilarity (\%) } \\
\hline & \multicolumn{4}{|c|}{ Intertidal } & \multicolumn{4}{|c|}{ Subtidal } & & & & & \\
\hline & UV & $\mathrm{H}$ & HM & $\mathrm{ZM}$ & UV & $\mathrm{Z}$ & HМ & $\mathrm{ZM}$ & H vs. $Z$ & HMI & ZMS & HMS & $\mathrm{ZMS}$ \\
\hline Gammarid amphipods & 1.7 & 15.0 & 55.6 & 131.1 & 0.1 & 38.2 & 27.3 & 36.0 & 18.8 & 29.8 & 16.8 & 26.2 & 30.0 \\
\hline Penaeid shrimp & 0.2 & 15.7 & 23.7 & 15.6 & 0.7 & 25.4 & 38.4 & 22.5 & 18.0 & 22.2 & 12.5 & 24.0 & 18.7 \\
\hline Callinectes sapidus & 0.0 & 4.6 & 4.0 & 3.7 & 0.0 & 5.4 & 5.5 & 11.0 & 8.3 & 8.8 & 11.4 & 8.8 & 9.0 \\
\hline Lagodon rhomboides & 0.0 & 1.0 & 2.2 & 1.5 & 0.0 & 7.2 & 2.6 & 2.4 & 12.2 & 7.5 & 11.0 & 7.9 & 5.9 \\
\hline Leiostomus xanthurus & 0.6 & 1.3 & 0.7 & 0.6 & 13.7 & 9.4 & 2.5 & 5.6 & 11.7 & 0.1 & 12.2 & 9.4 & 10.5 \\
\hline Isopods & 0.0 & 5.1 & 0.1 & 0.1 & 0.1 & 3.2 & 0.1 & 0.7 & 7.9 & 14.4 & 7.7 & 0.1 & 3.6 \\
\hline
\end{tabular}

Notes: Mean number of individuals per square meter, averaged over the four plots sampled for each treatment combination (UV, $\mathrm{H}, \mathrm{HM}$, and $\mathrm{ZM}$ ), are reported, as well as the percentage contributions to dissimilarity of taxa for a subset of the pairwise comparisons. Percentage contributions to dissimilarity of taxa cumulatively accounting for $50 \%$ of overall dissimilarity are reported in bold. Pairwise comparisons with unvegetated habitats (which differed from both vegetated patches and seagrass mimics for all taxa) and between Halodule and Zostera mimics deployed at the same depth (not significantly different) are not reported. 
TABLE 8. ANOVAs testing for differences in total epifaunal abundances between water depths and habitat treatments in the artificial seagrass colonization experiment.

\begin{tabular}{lrcc}
\hline \hline \multicolumn{1}{c}{ Source } & df & MS & $F$ \\
\hline $\mathrm{Si}$ & 1 & 27.0 & $88.7^{* * *}$ \\
$\mathrm{De}$ & 1 & 11.6 & 1.1 \\
$\mathrm{Tr}$ & 3 & 24.3 & $94.4^{* *}$ \\
$\mathrm{Si} \times \mathrm{De}$ & 1 & 10.3 & $33.8^{* * *}$ \\
$\mathrm{Si} \times \mathrm{Tr}$ & 3 & 0.3 & 0.9 \\
$\mathrm{De} \times \mathrm{Tr}$ & 3 & 1.7 & 0.7 \\
$\mathrm{Si} \times \mathrm{De} \times \mathrm{Tr}$ & 3 & $\mathbf{2 . 6}$ & $\mathbf{8 . 4}$ \\
Residual & 48 & 0.3 & \\
\hline
\end{tabular}

Notes: $\mathrm{Si}=$ site (random, two levels), $\mathrm{De}=$ depth (fixed, two levels: subtidal $[\mathrm{S}]$ and intertidal $[\mathrm{I}]$ ), $\mathrm{Tr}=$ treatment (fixed, four levels: natural submerged vegetation [V], unvegetated habitat [UV], shoalgrass mimic [HM], and eelgrass mimic [ZM]); $n=4$ plots. Significant terms that were examined further using SNK tests (see Appendix B) are shown in bold. All data were $\log (x+$ 1)-transformed. Cochran's test $C=0.27$ (not significant).

** $P<0.01 ; * * * P<0.001$.

were similar to the levels used in the low-level enrichment treatment in the mesocosm experiments. In all cases, nitrate concentrations measured in the field were below the levels associated with significant negative impacts on eelgrass (e.g., ranging up to approximately 15 and 1400 $\mu \mathrm{g} / \mathrm{L}$ for nitrates; Burkholder et al. 1992, 1994). Thus, the observed increase in nitrate concentrations in surface waters of Bogue Sound is unlikely to have negatively affected eelgrass, though the possibility that slight increases in nutrient levels may combine with other ongoing disturbances to exacerbate their impacts cannot be ruled out and needs to be addressed by studies focusing on the effects of multiple stressors on seagrasses.

Controlled, factorial experiments manipulating nutrient availability and water temperature, separately and in combination, are needed to determine the relative influences and joint effects of these anthropogenically based disturbances simultaneously affecting coastal marine habitats in many temperate and tropical regions. Stress associated with high temperatures or eutrophic conditions may exacerbate the negative effects of both climate change and water quality degradation by reducing photosynthetic activity, growth, reproductive rates, survivorship of seedlings, resistance to diseases, or by combinations of these mechanisms (den Hartog 1987, Short and Neckles 1999, Duarte 2002). Although both the surface water temperature and nutrient increase that we quantified for our study area are modest, even slightly elevated nutrient concentrations may act synergistically with high temperatures during the eelgrass growing season to adversely affect eelgrass directly or indirectly, through enhanced growth of epiphytes and macroalgae (e.g., Burkholder et al. 1992, Duarte 2002). This process could possibly magnify and accelerate loss of eelgrass relative to changes induced by increased temperature or anthropogenic eutrophication alone. Thus, we hypothesize that our observed decrease in density and biomass of Zostera marina but not Halodule wrightii over the past 20 years may be driven by the combined influences of temperature and nutrient availability.

To date, shoalgrass does not appear to have colonized habitat previously occupied by eelgrass. However, the possibility of future compensatory replacement by Halodule remains. Transplant experiments suggest that the primarily intertidal and shallow-subtidal distribution of Halodule may be partly caused by competitive interactions with Zostera at deeper locations. In contrast with Zostera transplants, which rapidly died in all habitats except Zostera beds, Halodule exhibited some survivorship in the deeper subtidal habitat, where at present natural Halodule patches are absent. Shoalgrass densities did not decline significantly within three months of transplantation into subtidal eelgrass beds and sand flats, and some shoots survived even after 6 months in subtidal unvegetated flats at one of the study sites (Fig. 5).

The demonstration that, both in the short (1 month after transplant) and longer (6 months) term, Halodule survivorship was lower within the Zostera bed than in unvegetated sand flats of similar depth suggests that interspecific competition - possibly through shading by the taller canopy of eelgrass, or through subsurface interactions among roots-may currently limit the distribution of Halodule. However, mortality of trans-

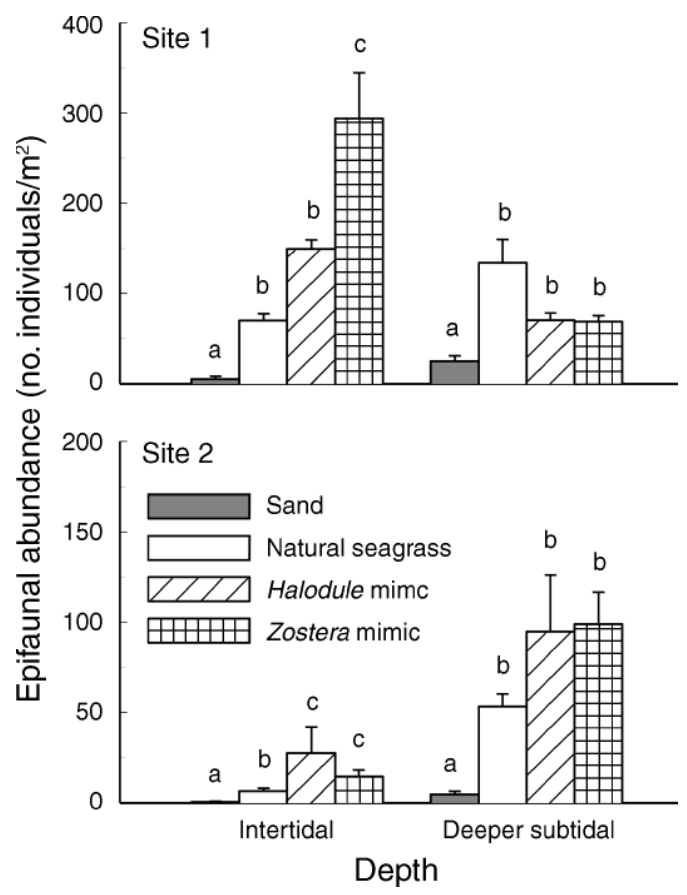

FIG. 9. Epifaunal abundance (mean $+\mathrm{SE})$ in unvegetated habitat, natural seagrass (Halodule at intertidal locations and Zostera at subtidal locations), and Halodule and Zostera mimics. Samples were collected in May 1993, two months after the deployment of seagrass mimics; $n=4$ plots. Lowercase letters denote groupings, as determined by a posteriori StudentNewman-Keuls tests for significant differences among habitats within each depth at each site $(P<0.05)$. 
plants was high overall even in these short-term experiments (6 months), raising the question of whether shoalgrass could persist at greater depths in the long term. In addition, we examined only growth and survival of larger plants, not the colonization and establishment processes. These processes clearly play an important role in determining the distribution of these seagrass species. The hypotheses that Halodule can naturally establish and grow successfully at deeper subtidal locations, and that competition with Zostera may limit its current depth range need to be confirmed by additional experiments investigating recruitment processes and mechanisms, such as interspecific competitive interactions, which may determine the early establishment and growth of Halodule plants.

The observed trend of declining eelgrass in the study area raises the question of how compositional and structural changes of seagrass affect associated faunal assemblages. Results of our field surveys and experiments indicate that loss of eelgrass is expected to lead to decreased abundances and diversity of faunal assemblages, and that expansion of shoalgrass into deeper locations would result in subtidal seagrass habitat that is functionally different from eelgrass.

Consistent with previous studies (e.g., Heck and Orth 1980, Beck et al. 2001), faunal abundances and diversity were greater in seagrass than in unvegetated habitats. Expansion of Halodule into subtidal habitat, therefore, would likely enhance faunal abundances relative to unvegetated habitat. However, comparisons of faunal abundances and benthic community structure among seagrass beds dominated by shoalgrass, eelgrass, or mixtures of these two species revealed that the two seagrass species host distinct faunal assemblages (Fig. 6). Infauna and epifauna were generally more abundant and diverse in Zostera and in mixed Halodule-Zostera beds than in Halodule beds (Figs. 7 and 8). This pattern was observed for highly abundant infaunal polychaetes in the families Spionidae, Nereidae, Capitellidae, Arabellidae, and Maldanidae, as well as for epifaunal species and species groups, including gammarid amphipods, penaeid shrimp, the pinfish, Lagodon rhomboides, and, in fall, the gastropod Bittium varium (Tables 5 and 7).

Our finding that Zostera-dominated seagrass beds contained greater infaunal and epifaunal abundances than seagrass beds dominated by Halodule may, in part, reflect differing total surface areas of seagrass blades, an important determinant of macrofaunal abundance (Heck and Orth 1980, Stoner 1980, Edgar and Robertson 1992). Estimates of total blade area per core, calculated by multiplying the number of seagrass shoots per core by the average number of blades per shoots and average blade lengths and widths, demonstrated seasonally greater leaf area of Zostera than Halodule beds. In spring, shallow-subtidal, mixed species beds and deeper subtidal Zostera beds had seagrass blade surface areas 3.7 (mixed species) and 4.4 (Zostera) times greater than intertidal Halodule beds (differences were significant in
SNK tests of the ANOVA interaction, site $\times$ seagrass bed type $\times$ season, $\left.F_{2,84}=5.9, P=0.004\right)$. In contrast, seagrass blade surface area in autumn was similar across all bed types (SNK tests). The possible effect of seagrass blade surface area on invertebrate abundances is corroborated by a positive correlation between total invertebrate abundance and seagrass blade surface area in spring ( $r=0.61, n=51$ cores, $P<0.05)$, but not in fall $(r=0.03, n=54, P>0.05)$. In spring, the abundance of fish from natural and artificial seagrass patches was also significantly and positively correlated to seagrass surface area $(r=0.47, n=48, P<0.05)$, but not to seagrass shoot density $(r=0.15, n=48, P>0.05)$.

An apparent contradiction to the result that seagrass blade surface area is related to differences in the fauna associated with Zostera and Halodule was the pattern of generally greater differences in abundance and diversity of invertebrates between seagrass bed types in fall than spring (no data on fish are available in fall). In fall, the growing season for Halodule and time of die-back for Zostera, total abundance of macrofauna in seagrass beds containing Zostera was over three times greater than in beds of Halodule. In contrast, in spring, when Zostera displays most growth, this difference was less than twofold (Fig. 7). Consideration of seasonality in recruitment patterns may reconcile this discrepancy. In spring, assemblages frequently contain large numbers of new recruits. Recruitment and subsequent growth and survival of organisms may be enhanced in eelgrass compared to shoalgrass beds, as suggested by the positive correlation between invertebrate abundances and seagrass surface area in spring. However, many recruits are too small to be retained by $1-\mathrm{mm}$ mesh sieves, and our sampling methods may have underestimated abundances during recruitment season. In fall, the numerically dominant invertebrates are generally older, with larger body sizes that are retained on our sieve. Thus, enhancement of infaunal abundances in eelgrass beds in spring and early summer may become evident in comparisons of larger infauna in fall, even though at that time Zostera has suffered some seasonal die-back and Halodule is at peak density.

Differences in epifaunal and infaunal assemblages among seagrass beds of differing composition are at least partially explained by above- and belowground differences in the structure of the deeper-rooted and longer- and wider-bladed Zostera marina and the more shallowly rooted and finer and more sparsely bladed Halodule wrightii. However, differences in seagrass species may be confounded with depth. Differences between the faunal assemblages that colonized Zostera and Halodule mimics deployed at identical depth were found only under certain conditions. At the intertidal depth of site 1 , epifaunal abundances were significantly greater in Zostera than Halodule mimics (Table 8, Fig. 9 ), indicating that structural characteristics of seagrass can contribute to influencing its faunal utilization, but failing to support the generality of this effect. Converse- 
ly, structurally-identical artificial seagrass patches deployed at different depths accumulated distinct epifaunal assemblages, indicating that depth contributes significantly to explaining differences in faunal assemblages among seagrass beds.

In the seagrass mimic experiment, the most significant differences were observed between assemblages of artificial and natural seagrass. Artificial seagrass units are unable to replicate functional variation between seagrass species resulting from differences in the assemblages of epiphytic algae they support (Jernakoff and Nielsen 1998, Pinckney and Micheli 1998, Trautman and Borowitzka 1999), their production of detritus (Cebrian et al. 1997), and their palatability to herbivores (Mariani and Alcoverro 1999). Such functions of seagrass, which were not adequately replicated by artificial seagrass units, are likely to contribute to differences between the faunal assemblages supported by Zostera and Halodule. Taken together, results of our field survey and experiments suggest that differences in the habitat value of Zostera and Halodule for associated fauna are not explained by morphological differences alone, but more likely by a combination of structural characteristics (resulting in variation in blade surface area), water depth occupied, and possibly the functional characteristics listed above.

Our data indicate that the species composition of seagrass beds is an important determinant of habitat value for invertebrates and fish, and that the observed decline of Zostera marina from North Carolina waters may have important negative consequences for faunal diversity and fisheries production of this region. Negative impacts would be expected in the event of overall loss of subtidal seagrass biomass, as greater faunal abundances and diversity were consistently associated with seagrass habitat compared to unvegetated habitat, regardless of the species composition and structural characteristics of seagrass patches. However, eelgrass and shoalgrass also differed in their value as habitat for estuarine fauna. Thus, even under the scenario of replacement of Zostera with Halodule, alteration of seagrass composition is expected to have negative impacts on the diversity and productivity of these important coastal ecosystems.

Loss or replacement of foundation species (e.g., "species that define much of the structure of a community by creating locally stable conditions for other species, and by modulating and stabilizing fundamental ecosystem processes" [Dayton 1972]) have clearly documented effects on biodiversity and ecological functioning of both marine and terrestrial ecosystems (e.g., Ellison et al. 2005, Schiel 2006). The loss of foundation tree species disrupts decomposition rates, nutrient fluxes, carbon sequestration, and energy flow within forest ecosystems and in associated aquatic systems (Ellison et al. 2005). Loss of kelp has major impacts on the structure and dynamics of kelp forest ecosystems (Steneck et al. 2002). For example, local kelp deforestation from sea urchin overgrazing in southern California was accompanied by $40 \%$ reduction in sessile invertebrate diversity, reduced abundance for $90 \%$ of species, and major alteration of food web interactions (Graham 2004). Loss and degradation of oyster reefs in temperate estuaries results in decreased fisheries production and degradation of water quality (Jackson et al. 2001).

In this study, we find that community-wide and functional changes might occur also through more subtle alterations of the relative abundances of different foundation species, mediated through changes in environmental conditions. Ecosystems structured through the presence of foundation species, including seagrass meadows, salt marshes, and algal beds, are expected to be particularly vulnerable to environmental change close to limits in their physiological tolerance, where associated assemblages and ecological processes are affected by environmental change both directly and indirectly, through decline or substitutions of foundation species. Such indirect effects might overwhelm direct influences of disturbances on species distributions. For example, 18-year monitoring of the biological effects of water warming from a power plant effluents in central California showed that a $3.5^{\circ} \mathrm{C}$ rise in water temperature did not result in species with warm-water affinities replacing colder-water species. Instead, significant changes in 150 of 174 species of algae and invertebrates appeared to be cascading effects of declines and species replacements in habitat-forming algal species, foliose red algae at intertidal locations, and kelp subtidally (Schiel et al. 2004).

An understanding of the role of different species in shaping communities and maintaining ecosystem functions is critical for predicting community-wide consequences of both local and regional disturbances. Foundation species clearly play key roles in structuring communities. By focusing on responses of foundation species to disturbance and on resulting alteration of their functional value as resources for other species, we can increase our ability to predict community-wide consequences of environmental change, including anthropogenic nutrient loading and climate warming.

\section{ACKNOWLEDGMENTS}

We thank D. Colby, M. Fonseca, J. Kenworthy, E. Irlandi, H. Lenihan, H. Summerson, and L. Wood for their help and advice. W. Kirby-Smith provided the long-term temperature data. A. N. Hendrix, L. Hill, C. Hooper, A. Maxson, M. V. Chiarugi, and B. Orlando helped with fieldwork, construction of artificial seagrass patches, and sample sorting. L. Hill conducted the water sampling and nutrient analyses. C. V. Kappel and four anonymous reviewers improved earlier drafts of this paper. J. Rivera was supported by NOAA during the earlier years of this study. The middle years included support by a grant from NOAA to C. H. Peterson through the Cooperative Institute of Fisheries Oceanography (CIFO). Later years of support came from the UNC Institute of Marine Sciences (C. H. Peterson and M. Bishop) and by EPA STAR grant R832223 (F. Micheli). 


\section{Literature Cited}

Beck, M. W., et al. 2001. The identification, conservation, and management of estuarine and marine nurseries for fish and invertebrates. BioScience 51:633-641.

Bjork, M., J. Uku, A. Weil, and S. Beer. 1999. Photosynthetic tolerances to desiccation of tropical intertidal seagrasses. Marine Ecology Progress Series 191:121-126.

Bray, J. R., and J. T. Curtis. 1957. An ordination of the upland forest communities of Southern Wisconsin. Ecological Monographs 27:325-349.

Burkholder, J. M., H. B. Glasgow, Jr., and J. E. Cooke. 1994. Comparative effects of water-column nitrate enrichment on eelgrass Zostera marina, shoalgrass Halodule wrightii, and widgeongrass Ruppia maritima. Marine Ecology Progress Series 105:121-138.

Burkholder, J. M., K. M. Mason, and H. B. Glasgow, Jr. 1992. Water-column nitrate enrichment promotes decline of eelgrass Zostera marina: evidence from seasonal mesocosm experiments. Marine Ecology Progress Series 81:163-178.

Cebrian, J., C. M. Duarte, N. Marba, and S. Enriquez. 1997. Magnitude and fate of the production of four co-occurring western Mediterranean seagrass species. Marine Ecology Progress Series 155:29-44.

Clarke, K. R. 1993. Non-parametric multivariate analyses of changes in community structure. Australian Journal of Ecology 18:117-143.

Clarke, K. R., and R. M. Warwick. 1994. Change in marine communities: an approach to statistical analysis and interpretation. Natural Environment Research Council, Swindon, UK.

Connell, J. H. 1972. Community interactions on marine rocky intertidal shores. Annual Review of Ecology and Systematics 3:169-192.

Dalla Via, J., C. Sturmbauer, G. Schonweger, E. Sotze, S. Mathekowitsch, M. Stifter, and R. Rieger. 1998. Light gradients and meadow structure in Posidonia oceanica: ecomorphological and functional correlates. Marine Ecology Progress Series 163:267-278.

Dayton, P. K. 1972. Toward an understanding of community resilience and the potential effects of enrichments to the benthos at McMurdo Sound, Antarctica. Pages 81-96 in B. C. Parker, editor. Proceedings of the colloquium on conservation problems in Antarctica. Allen Press, Lawrence, Kansas, USA.

den Hartog, C. 1987. "Wasting disease" and other dynamic phenomena in Zostera beds. Aquatic Botany 27:3-14.

Dennison, W. C., R. J. Orth, K. A. Moore, J. C. Stevenson, V. Carter, S. Kollar, P. W. Bergstrom, and R. A. Batiuk. 1993. Assessing water quality with submersed aquatic vegetation. BioScience 43:86-94.

Duarte, C. M. 2002. The future of seagrass meadows. Environmental Conservation 29:192-206.

Edgar, G. J., and A. I. Robertson. 1992. The influence of seagrass structure on the distribution and abundance of mobile epifauna: pattern and process in a Western Australia Amphibolis bed. Journal of Experimental Marine Biology and Ecology 160:13-31.

Ellison, A. M., et al. 2005. Loss of foundation species: consequences for the structure and dynamics of forested ecosystems. Frontiers in Ecology and the Environment 3: 479-486.

Fenchel, T. 1977. Aspects of the decomposition of seagrasses. Pages 123-146 in C. P. McRoy and C. Helfferich, editors. Seagrass ecosystems: a scientific perspective. Dekker, New York, New York, USA.

Glémarec, M. 1997. The Bay of Brest: environmental disturbance and its impact on the biota. Annales de '1 Institute Oceanographique 73:113-122.

Graham, M. H. 2004. Effects of local deforestation on the diversity and structure of southern California giant kelp forest food webs. Ecosystems 7:341-357.
Hale, J. A., T. K. Frazer, D. A. Tomasko, and M. O. Hall. 2004. Changes in the distribution of seagrass species along Florida's central Gulf Coast: Iverson and Bittaker revisited. Estuaries 27:36-43.

Harley, C. D. G., A. R. Hughes, K. M. Hultgren, B. G. Miner, C. J. B. Sorte, C. S. Thornber, L. F. Rodriguez, L. Tomanek, and S. L. Williams. 2006. The impact of climate change in coastal marine systems. Ecology Letters 9:228-241.

Harrison, P. G., and K. H. Mann. 1975. Detritus formation from eelgrass (Zostera marina L.): the relative effects of fragmentation, leaching and decay. Limnology and Oceanography 20:924-934.

Heck, K. L., Jr., and R. J. Orth. 1980. Seagrass habitats: the roles of habitat complexity, competition and predation in structuring associated fish and motile macroinvertebrate assemblages. Pages 449-464 in V. S. Kennedy, editor. Estuarine perspectives. Academic Press, New York, New York, USA.

Heck, K. L., Jr., and T. Thoman. 1984. The nursery role of seagrass meadows in the upper and lower reaches of the Chesapeake Bay. Estuaries 7:70-92.

Hemminga, M., and C. M. Duarte. 2000. Seagrass ecology. Cambridge University Press, Cambridge, UK.

Hughes, T. P., et al. 2003. Climate change, human impacts and the resilience of coral reefs. Science 301:929-934.

Intergovernmental Panel on Climate Change. 2007. Impacts, adaptation, and vulnerability. Contribution of Working Group II to the Fourth Assessment Report of the Intergovernmental Panel on Climate Change. Cambridge University Press, Cambridge, UK.

Jackson, J. B. C., et al. 2001. Historical overfishing and the recent collapse of coastal ecosystems. Science 293:629-638.

Jernakoff, P., and J. Nielsen. 1998. Plant-animal associations in two species of seagrasses in Western Australia. Aquatic Botany 60:359-376.

Johnson, M. R., S. L. Williams, C. H. Lieberman, and A. Solbak. 2003. Changes in the abundance of the seagrasses Zostera marina L. (eelgrass) and Ruppia maritima L. (widgeongrass) in San Diego, California, following an El Niño event. Estuaries 26:106-115.

Kareiva, P. M., J. G. Kingsolver, and R. B. Huey. 1993. Biotic interactions and global change. Sinauer, Sunderland, Massachusetts, USA.

Kenworthy, W. J. 1981. The interrelationship between seagrasses, Zostera marina and Halodule wrightii, and the physical and chemical properties of sediments in a midAtlantic coastal plain estuary near Beaufort, North Carolina (USA). Thesis. University of Virginia, Charlottesville, Virginia, USA.

Keser, M., J. T. Swenarton, J. M. Vozarik, and J. F. Foertch. 2003. Decline in eelgrass (Zostera marina L.) in Long Island Sound near Millstone Point, Connecticut (USA) unrelated to thermal input. Journal of Sea Research 49:11-26.

Lotze, H. K., H. S. Lenihan, B. J. Bourque, R. H. Bradbury, R. G. Cooke, M. C. Kay, S. M. Kidwell, M. X. Kirby, C. H. Peterson, and J. B. C. Jackson. 2006. Depletion, degradation, and recovery potential of estuaries and coastal seas. Science 312:1806-1809.

Lubchenco, J., S. A. Navarrete, B. N. Tissot, and J. C. Castilla. 1993. Possible ecological responses to global climate change: nearshore benthic biota of Northeastern Pacific coastal ecosystems. Pages 147-166 in H. A. Mooney, E. R. Fuentes, and B. I. Kronberg, editors. Earth system responses to global climate change: contrasts between North and South America. Academic Press, San Diego, California, USA.

Marbà, N., and C. M. Duarte. 1997. Interannual changes in seagrass (Posidonia oceanica) growth and environmental change in the Spanish Mediterranean littoral. Limnology and Oceanography $42: 800-810$.

Mariani, S., and T. Alcoverro. 1999. A multiple-choice feedingpreference experiment utilizing seagrasses with a natural 
population of herbivorous fishes. Marine Ecology Progress Series 189:295-299.

Nixon, S. W., S. Granger, B. A. Buckley, M. Lamont, and B. Rowel. 2004. A one hundred and seventeen year coastal water temperature record from Woods Hole, Massachusetts. Estuaries 27:397-404.

Orth, R. J., K. L. Heck, Jr., and J. van Montfrans. 1984. Faunal communities in seagrass beds: a review of the influence of plant structure and prey characteristics on predator-prey relationships. Estuaries 7:339-350.

Peterson, C. H. 1979. Predation, competitive exclusion, and diversity in the soft-sediment benthic communities of estuaries and lagoons. Pages 233-264 in R. J. Livingston, editor. Ecological processes in coastal and marine systems. Plenum Press, New York, New York, USA.

Peterson, C. H., R. A. Luettich, Jr., F. Micheli, and G. A. Skilleter. 2004. Flow damping under seagrass canopies of differing structure. Marine Ecology Progress Series 268:8192.

Phillips, R. C. 1960. Observations on the ecology and distribution of the Florida sea grasses. Professional Papers Series, Florida Board of Conservation 2:1-72.

Pinckney, J. L., and F. Micheli. 1998. Microalgae on seagrass mimics: does epiphyte community structure differ from live seagrasses? Journal of Experimental Marine Biology and Ecology 221:59-70.

Schiel, D. R. 2006. Rivets or bolts? When single species count in the function of temperate rocky reef communities. Journal of Experimental Marine Biology and Ecology 338:233-252.

Schiel, D. R., J. R. Steinbeck, and M. S. Foster. 2004. Ten years of induced ocean warming causes comprehensive changes in marine benthic communities. Ecology 85:1833-1839.

Shores, J. W. 1994. Seasonal variation of $\delta^{15} \mathrm{~N}$ of surface coastal plankton at Beaufort Inlet, NC: implications concerning source nitrogen and trophic dynamics. Thesis. University of North Carolina at Chapel Hill, North Carolina, USA.

Short, F. T., and H. A. Neckles. 1999. The effects of global climate change on seagrasses. Aquatic Botany 63:169-196.
Short, F. T., and S. Wyllie-Echeverria. 1996. Natural and human induced disturbance of seagrasses. Environmental Conservation 23:17-27.

Somero, G. N. 2002. Thermal physiology and vertical zonation of intertidal animals: optima, limits, and costs of living. Integrative and Comparative Biology 42:780-789.

Steneck, R. S., M. H. Graham, B. J. Bourque, D. Corbett, J. M. Erlandson, J. A. Estes, and M. J. Tegner. 2002. Kelp forest ecosystems: biodiversity, stability, resilience and future. Environmental Conservation 29:436-459.

Stoner, A. W. 1980. Perception and choice of substratum by epifaunal amphipods associated with seagrasses. Marine Ecology Progress Series 3:105-111.

Thayer, G. W. 1974. Identity and regulation of nutrients limiting phytoplankton production in the shallow estuaries near Beaufort, NC. Oecologia 14:76-92.

Thayer, G. W., W. J. Kenworthy, and M. S. Fonseca. 1984. The ecology of eelgrass meadows of the Atlantic coast: a community profile. FWS/OBS-84/02. U.S. Fish and Wildlife Service, Washington, D.C., USA.

Thayer, G. W., P. L. Parker, and M. W. LaCroix. 1977. Seasonal distribution and changes in the nutritional quality of living, dead, and detrital fractions of Zostera marina. Journal of Experimental Marine Biology and Ecology 30: 109-127.

Trautman, D. A., and M. A. Borowitzka. 1999. Distribution of the epiphytic organisms on Posidonia australis and P. sinuosa, two seagrasses with differing leaf morphology. Marine Ecology Progress Series 179:215-229.

Tribble, G. W. 1981. Reef-based herbivores and the distribution of two seagrasses (Syringodium filiforme and Thalassia testudinum) in the San Blas Islands (Western Caribbean). Marine Biology 65:277-281.

Williams, S. L. 1987. Competition between the seagrasses Thalassia testudinum and Syringodium filiforme in a Caribbean lagoon. Marine Ecology Progress Series. 35:91-98.

\section{APPENDIX A}

SNK tests conducted after ANOVAs comparing shoot density of seagrass plugs transplanted into intertidal and subtidal habitats at two sites in Middle Marsh, North Carolina, USA (Ecological Archives M078-008-A1).

\section{APPENDIX B}

SNK tests conducted after ANOVAs comparing total invertebrate abundances, number of invertebrate families, and total infaunal and epifaunal abundances from benthic cores collected at different depths and within both vegetated and unvegetated habitats (Ecological Archives M078-008-A2). 